\title{
The Determinants of Trade Costs in the East African Community
}

\author{
Sheila Mwendwa Kaminchia* \\ University of Nottingham, Nottingham, United Kingdom
}

\begin{abstract}
This paper assesses the East African Community's (EAC) effectiveness in integrating member countries by lowering total bilateral trade costs. First, information is provided on the size and distribution of bilateral trade costs among 16 manufacturing industries over the period 1990 2012 for a sample comprising five EAC countries and 87 of their trade partners. The estimates indicate that it costs on average three times more for an EAC country to trade manufactured goods with another EAC country than to trade those goods domestically. The estimates also indicate that it costs on average eight times more for an EAC country to trade manufactured goods with a non-EAC country than to trade those goods domestically. This paper then shows the importance of natural and policyrelated factors in determining the trade costs.
\end{abstract}

JEL Classifications: F10, F15

Keywords: Trade costs, Gravity, East African Community, Trade integration

* Corresponding Author: Sheila Mwendwa Kaminchia; Ph.D Candidate, School of Economics, Sir Clive Granger Building, University of Nottingham, University Park, Nottingham, NG7 2RD. Tel: +44 777885 1994, E-mail: Sheila.Kaminchia@nottingham.ac.uk

Acknowledgments: The author thanks Dr. Roberto Bonfatti and Dr. Alejandro Riaño for their guidance and comments on this paper and earlier drafts. This paper has also benefited from comments and suggestions received from Professor Gianni De Fraja, Professor Oliver Morrissey and other participants at the Postgraduate Research Student Presentations, School of Economics, University of Nottingham. The authors also thanks the anonymous reviewer for their valuable comments and suggestions to improve this paper. Any remaining errors in this study are the author's alone. 


\section{Introduction}

There is little information in the empirical literature on trade in Africa that considers the size and distribution of cross-border trade costs among manufacturing industries. Yet this information is essential for micro-level analysis of trade policy effects. This paper fills this information gap in the empirical literature by focusing on these aspects of trade in East African countries.

This paper uses the total bilateral trade costs measure, which captures all the costs of trading a good between two countries relative to the cost of trading it domestically in each of the trading countries. Fully integrated trading partners would have a total bilateral trade costs value of 1 , meaning that the cost of international trade would be equal to the cost of domestic trade. The total bilateral trade costs are estimated using the inverse-gravity method developed in Chen and Novy (2011), which is based on the theoretical framework for the gravity equation presented in Anderson and van Wincoop (2003, 2004).

Total bilateral trade cost estimates at a disaggregated level of production for advanced economies have been analyzed in the empirical literature (Chen and Novy 2011, Jacks et al. 2010, 2011, Novy 2013). Analysis of trade costs for developing economies (including those in Africa) is limited to an aggregated level of production, that is, at the International Standard Industrial Classification (ISIC) one-digit level (Arvis et al. 2016). The present paper extends the literature by estimating and analyzing the total bilateral trade costs related to manufactured goods at the ISIC Revision (Rev.) 3 two-digit level of production for East African countries.

This paper first presents estimates of total bilateral trade costs for member countries of the East African Community (EAC) with respect to each other and 87 of their trade partners. The paper then assesses the effectiveness of EAC membership in integrating member countries by way of lowering the total bilateral trade costs.

Trade policies have been implemented by EAC governments to lower the cost of crossborder trade among member countries. Among these policy measures is elimination of import tariffs, reforms to customs procedures, and infrastructure upgrades. The extent to which these policies have lowered the total cost of engaging in cross-border trade for manufacturing industries in the region remains to be determined. To determine this, industry-level total bilateral trade cost estimates for the EAC are required, but there is a lack of these in the empirical literature.

The purpose of this paper is to estimate the total bilateral trade costs of EAC countries for 16 industries in the manufacturing sector. The paper focuses on the industry-level because working with disaggregated data paints a more accurate picture of trade costs. The paper answers the question: How high are the total bilateral trade costs facing manufacturing industries in the EAC? Credible estimates of total bilateral trade costs would have the expected relationship with known proxies of trade costs as established in the gravity literature.

Practical methods to derive comprehensive measures of cross-border trade costs have been developed based on the gravity equation (Jacks et al. 2010, 2011, Chen and Novy 2011, Novy 
2013). "Practical" is in the sense that not all trade costs can be observed to be captured in data, and not all trade costs are the same for every cross-border transaction so collating and aggregating data on individual transactions would be necessary (Jacks et al. 2011). One such method of doing so is the inverse-gravity framework presented in Chen and Novy (2011). The framework adopts a broad definition of trade costs as all the "costs incurred in getting a good to a final user other than the marginal cost of producing the good itself" (Anderson and van Wincoop 2004, p. 691). This definition permits a wide range of determining factors of trade frictions, including marketing and sales-related costs, taxes, transportation, customs procedures, payments, financing and insurance, language differences, exchange rate arrangements, and trade agreements (Jacks et al. 2011, Anderson and van Wincoop 2004).

The framework of Chen and Novy (2011) infers a single measure of all these trade costs from observed production and trade flow data. This is done by combining four unidirectional, industry-level gravity equations to obtain an expression that defines the ratio of bilateral to domestic trade costs in terms of the ratio of domestic to bilateral trade flows, which is scaled by an industry-specific elasticity of substitution parameter. The single measure is specific to a country-pair and industry, and it gives the size of all the costs of trading a good between two countries relative to the cost of trading the good domestically in each country. Studies that have applied this method to data for advanced economies find the total bilateral trade costs estimates have the expected relationship with known proxies for trade frictions among those countries (Jacks et al. 2010, 2011, Novy 2013).

The method is particularly useful to the present study because it permits the total bilateral trade costs to be calculated from disaggregated data on production and bilateral trade flows. The estimates derived from EAC data will therefore vary each year by country-pair at the industry level. The estimates can then be used to analyze trade policy effects over time across industries and by trade partner. One issue with the inverse-gravity method of Chen and Novy (2011), however, is that the total bilateral trade costs estimates depend on assumptions made about the elasticity of substitution parameter.

This paper exploits the availability of data on production and export values for manufactured goods classified at the ISIC Rev.3 two-digit level for five EAC countries: Burundi, Kenya, Rwanda, Tanzania, and Uganda. Estimates of total bilateral trade costs are calculated for 16 industries and for trade between the five EAC countries and 87 of their trade partners in each year of period 1990 2012. Elasticity of substitution estimates are first calculated following the method in Feenstra (1994), which are then used to calculate total bilateral trade costs following the method of Chen and Novy (2011). The resulting elasticity of substitution estimates for the 16 industries range from 3 to 14 and average 7 . The estimates vary across industries and are assumed to be the same for the entire EAC market. The total bilateral trade costs estimates average eight (excluding outliers for two industries: nonmetallic mineral products and coke manufacturing, and refined petroleum products). This means that it costs an EAC country on average eight times more to trade manufactured goods with another country than to trade the goods domestically.

In terms of the distribution of total bilateral trade costs across country-pairs, the trade costs estimates are larger with respect to trade partners located farther away from the EAC 
and are smaller with respect to coastal partners as well as with EAC countries that share a trade agreement and colonial history. Regression results show that for EAC countries, trade agreements are an important determinant of total bilateral trade costs even after controlling for geographical distance. Additionally, higher responses of total bilateral trade costs to the determinants are obtained from industry-level total bilateral trade costs as compared with responses estimated from sector-level total bilateral trade costs (that is, total manufacturing). In terms of trends over time, the total bilateral trade costs estimates for intra-EAC trade turn downwards after 1999 from an average of three to two, which coincides with the enforcement of the EAC Treaty in 2000. Total bilateral trade costs for extra-EAC trade, however, shows an upward trend from an average of seven to 10. Subsequent Ordinary Least Squares (OLS) regressions show EAC trade agreement to be an important determinant of total bilateral trade costs.

In terms of the distribution of total bilateral trade costs estimates across industries, industries producing goods characterized by higher weight-to-value ratios and higher import tariff rates have higher total bilateral trade costs. Regression results also show heterogeneous influences of the determinants on total bilateral trade costs across industries. The EAC trade agreement is found to have a weaker influence on the total bilateral trade costs of industries that predominantly trade outside the region.

Robustness checks are conducted to assess how the total bilateral trade costs estimates change with the choice of elasticity of substitution parameter. The checks reveal that total bilateral trade costs calculated using an industry-specific elasticity of substitution parameter are larger in size and variance compared to estimates derived using an elasticity of substitution parameter that is common across industries. Chen and Novy (2011) find it suitable to estimate total bilateral trade costs using an elasticity of substitution parameter that is measured at the same level of disaggregation to adequately capture industry-level effects.

This paper is related to the literature that estimates and analyzes total bilateral trade costs (Jacks et al. 2010, 2011, Chen and Novy 2011, Novy 2013). This literature has identified geographical distance, transportation costs, technical barriers to trade, and public bureaucracy as important contributors to total bilateral trade costs. The estimated total bilateral trade costs are found to be lower in the presence of a common border, language, colonial ties, and religion as well as membership in a regional trade agreement, higher level of industrialization, and a fixed exchange rate regime. The studies also find a negative relationship between cross-border trade costs and cross-border trade flows, with the strength of the relationship dependent on whether disaggregated production data is used, and on the import content of traded goods (Milner and McGowan 2013). Specific to EAC countries, there are total bilateral trade costs estimates derived using the Chen and Novy (2011) method at an aggregated level of production published in the ESCAP-World Bank trade costs database. These estimates for the period 1996 2010 are analyzed in Arvis et al. (2016). The present study contributes to this literature total bilateral trade costs estimates at the two-digit level of production for EAC countries and evidence on the determinants thereof.

The rest of this paper is organized as follows: an overview of the pattern of production and trade in manufactured goods in the EAC is provided in Section 2. Section 3 provides 
a description of the data. Section 4 outlines the methods used to estimate the elasticity of substitution parameter and total bilateral trade costs for the EAC. The total bilateral trade costs estimates are presented in Section 5 with an evaluation in relation to known proxies of trade costs provided in Section 6. The sensitivity of the total bilateral trade costs estimates to underlying assumptions is assessed in Section 7. Conclusions and policy implications are presented in Sections 8 and 9, respectively.

\section{Background: Production and Trade of Manufactured Output}

The manufacturing sector in the EAC is modest, on average contributing less than $10 \%$ to EAC countries' gross domestic product (Figure 1). In terms of exports, manufactured goods constitute about $30 \%$ and $20 \%$ of Kenya's and Tanzania's merchandise exports, respectively, and even less for those of the smaller member countries. Still, the EAC's hopes for industrial growth and job creation remain in this sector. Partner states have jointly committed to raise the share of manufacturing in total output to $25 \%$ by the year 2032 .

Figure 1. Size of EAC's manufacturing sector

(1990 2012)

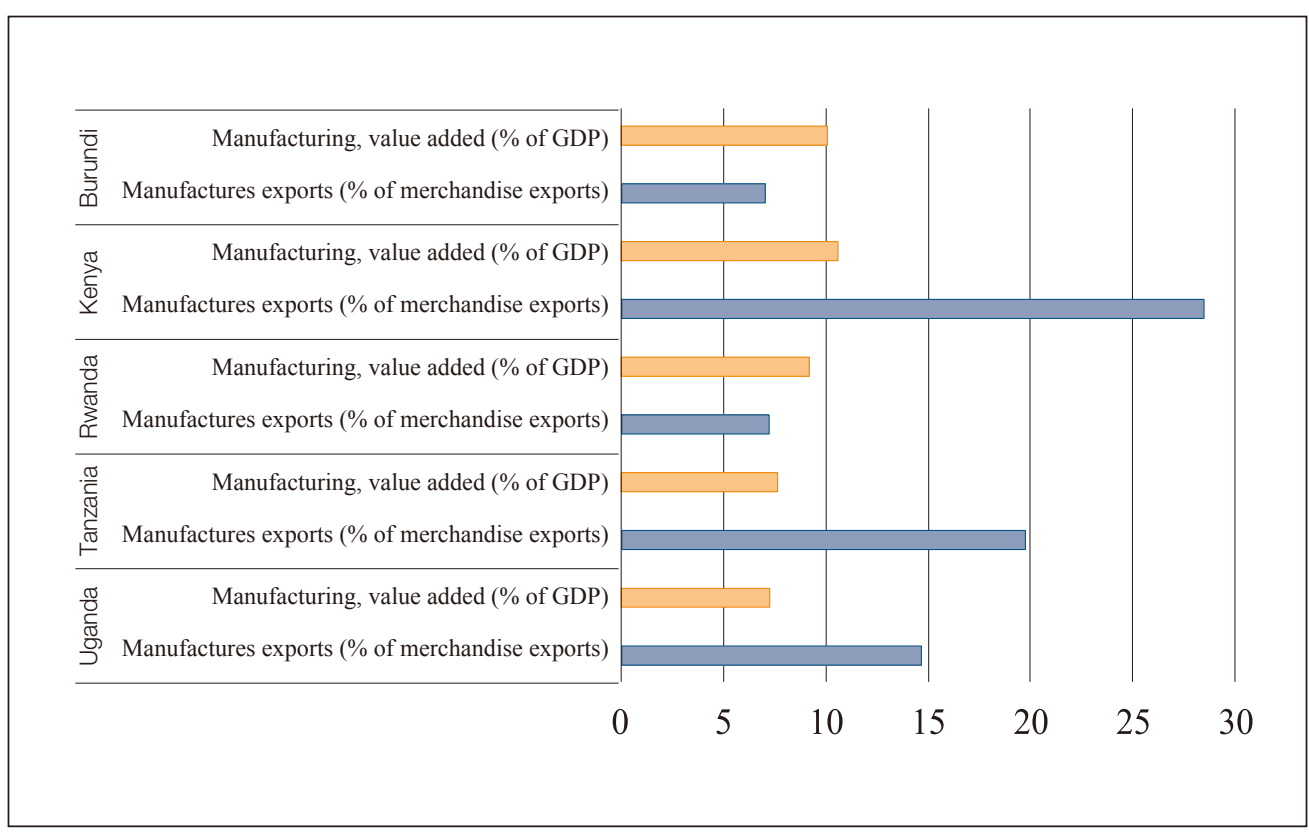

(Source) World Bank's World Development Indicators online database 
During the period 1990 2012, food and beverages made up most of the manufactured output of EAC countries (see Figure 2 and Panel A of Appendix 1). Other notable industries were those producing chemicals and chemical products, non-metallic mineral products, basic metals, and rubber and plastics products. Over time, the composition of EAC manufactured output did not change significantly.

\section{Figure 2. Composition of manufactured output of EAC countries}

(1990 2012)

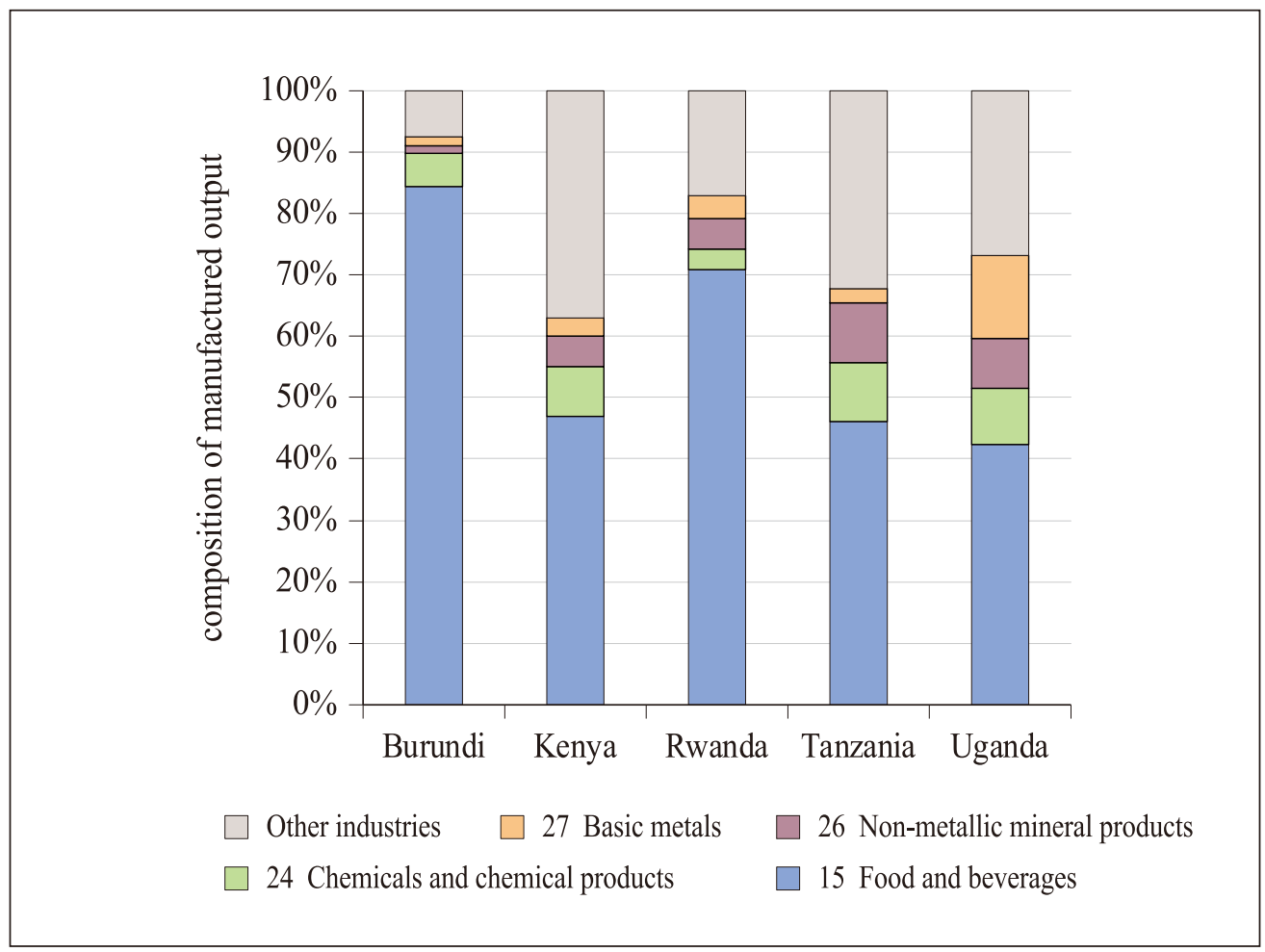

(Source) Author's calculations based on data from INDSTAT2 online database

Little of this output was traded within the EAC and in general. About $1 \%$ of Kenya's manufactured food and beverages was exported within the EAC while Tanzania exported 2\%, compared with $7 \%$ of manufactured food and beverages exported outside the EAC by each country (see Panels B and C of Appendix 1). ${ }^{1}$ Kenya, however, exported a larger share of its output of chemicals and chemical products, basic metals, and rubber and plastics products within the EAC. Tanzania exported a larger share of its output of refined petroleum products within the EAC while Uganda exported a comparably larger share of basic metals, chemicals

${ }^{1}$ Concordance table HS Combined to ISIC Rev.3 available from the World Bank's World Integrated Trade Solution (WITS) website was used to map goods traded under the Harmonized System (HS) of classification into ISIC product categories. 
and chemical products, and non-metallic mineral products within the EAC. In general, more tobacco, fuel, chemical, rubber, plastic, and non-metallic mineral products were traded within the EAC compared with food and beverages, apparel, leather, and wood products, which were predominantly traded with non-EAC partners.

Figure 3 shows the composition of the total value of manufactured goods traded among EAC countries and with 87 non-EAC partners in the period 1990 2012. ${ }^{2}$ Food and beverages, and chemicals and chemical products have the largest share in EAC trade, followed by non-metallic mineral products, basic metals, and textiles. The composition of trade in manufactured goods (exports plus imports) differs between intra-EAC and extra-EAC trade, with a more pronounced difference for Burundi and Uganda.

\section{Figure 3. Composition of trade in manufactured goods by EAC countries}

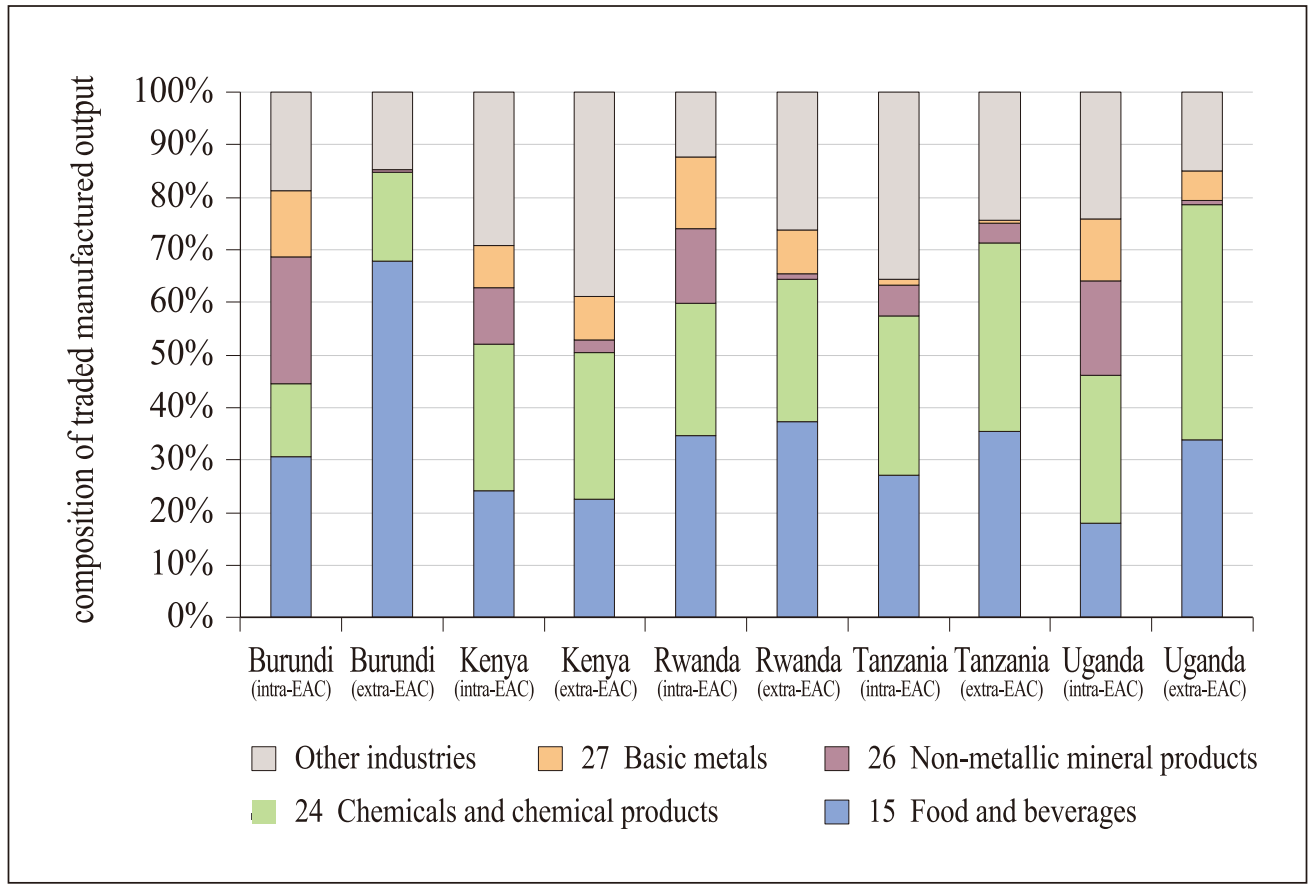

(Source) Author's calculations based on data from COMTRADE online database. 


\section{Data Description}

Sample: The sample for this study comprises annual data for the period 1990 2012 for five EAC countries, namely Burundi, Kenya, Rwanda, Tanzania, and Uganda, and 87 nonEAC countries. In total, the sample has 260 country-pairs, with 10 comprising an EAC exporter and an EAC importer (representing intra-EAC trade) and 250 comprising an EAC exporter and a non-EAC importer (representing extra-EAC trade). See Appendix 2 for the list of countries and territories included in the sample. Sixteen ISIC Rev.3 categories at the two-digit level are sampled; this list is provided in Appendix 3. The panel is not balanced and reflects the availability of data on domestic production and two-way export flow values in manufactured goods for a country-pair.

Domestic production: Data on domestic production is comprised of the output values for the 16 manufactured product groups measured in current US dollars. The data is sourced from the United Nations Industrial Development Organization's Industrial Statistics (INDSTAT2) 2015 online database. Data is available for all countries in the sample until 2012 but with gaps. Data gaps for Egypt, Kenya, South Africa, Tunisia, Uganda, and Zambia are filled by extrapolation using indices of industrial production from INDSTAT2 and inflating the indices using the gross domestic product (GDP) deflator for each country. Data on the GDP deflator is sourced from the World Bank's World Development Indicators (WDI).

Data for Tanzania for the period 2008 2012 comprises the gross output of industrial establishments with 10 or more workers measured in millions of Tanzania shillings. The data is published by the Tanzania National Bureau of Statistics in the Statistical Abstract. The data captures about $99 \%$ of total output from the manufacturing sector in Tanzania. The data is converted to current US dollars using the annual average exchange rate between the Tanzania shilling and the US dollar, which is obtained from WDI. The output data is then extrapolated backward to 2000 using indices of industrial production (obtained from INDSTAT2) and then inflated using the GDP deflator for Tanzania. From 1994 to 1999, the data is output values reported in INDSTAT2.

Domestic production data for Rwanda during the period 1999 2012 is GDP measured at current prices in billions of Rwandan francs, converted to US dollars using the annual average exchange rate between the Rwandan franc and the US dollar. Production data is sourced from the GDP-National Accounts, 2015 Statistical Report of the National Institute of Statistics of Rwanda (NISR). This data is grouped into eight broad product categories, which were split into 16 ISIC groups using the product line weights used to construct Rwanda's producer price index that are published in the Statistical Yearbook 2015 of the NISR. The exchange rate data for Rwanda is from WDI.

Trade flows: Trade flow data is bilateral export and import volume (measured in kilograms) and export and import values (measured in US dollars) sourced from the United Nations Commodity Trade Statistics (COMTRADE) online database. For each country-pair in the sample, each ISIC category, and each year from 1990 to 2012, I collect data on the 
F.O. $\mathrm{B}^{3}$ value and volume of exports from the exporter country to the importer country and data on the F.O.B value and volume of exports from the importer country to the exporter country. The cost of insurance and freight services is excluded from these trade flow values.

For purposes of estimating the elasticity of substitution among traded goods, I also collect data on the cost, insurance, and freight (C.I.F.) ${ }^{4}$ value of imports of goods (for each ISIC category) from each importer country into each exporter country. Trade flow data classified under the Harmonized System (HS) are grouped into ISIC categories using the HS Combined to ISIC Rev.3 concordance table available from the World Bank's World Integrated Trade Solution (WITS) website. Data for 196 countries and territories that traded with EAC countries over the period of 1990 to 2012 are used to estimate the elasticity of the substitution parameter. Only 87 of these countries and territories have the ISIC two-digit level production data needed to calculate total bilateral trade costs. Data on export values and export volumes reported by Kenya has gaps for periods 1993 1996 and 2011 2012, so data on imports from Kenya as reported by Kenya's trade partners is used instead for the entire sample period.

Gravity variables: Data on the simple (great-circle) distance between two countries, World Trade Organization (WTO) membership start dates, and binary variables for common language, common border, common colonial ties, and being landlocked are from Center d'Études Prospectives et d'Informations Internationales (CEPII) files sourced from the UNCTAD Virtual Institute on Trade and Development. EAC and COMESA membership start dates are obtained from the websites of the EAC and Common Market for Eastern and Southern Africa (COMESA) Secretariats, respectively.

Import tariff rates: Data on the Effectively Applied (AHS) tariff rates at the ISIC Rev.3 two-digit level for each country in the sample are obtained from the UNCTAD Trade Analysis Information System accessed through the World Bank's WITS website.

\section{Theoretical Background of the Estimation of Total Bilateral Trade Costs}

\section{A. The gravity equation}

Estimates of total bilateral trade costs are derived from data on production and exports of manufactured goods based on the theoretical framework developed in Anderson and van Wincoop (2003). In this framework, trade of goods between two countries is assumed to be demand-driven. The utility that consumers derive from consumption is defined in terms of a constant elasticity of substitution function that sums up expenditure on consumed goods weighted by the degree of substitutability among goods that are available for consumption. Demand in country $j$ for goods produced in country $i$ is expressed in the form of a gravity equation defined as follows:

${ }^{3}$ Free on board valuation.

${ }^{4}$ Cost, insurance, and freight valuation. 


$$
x_{i j}=\frac{y_{i} y_{j}}{y^{W}}\left(\frac{t_{i j}}{P_{i} P_{j}}\right)^{1-\sigma}, \quad \sigma>1
$$

where $x_{i j}$ denotes exports from country $i$ to country $j, y_{i}$ denotes GDP of country $i, y_{j}$ denotes GDP of country $j, y^{W}$ is world GDP, $t_{i j}$ denotes the trade cost factor between countries $i$ and $j, P_{i}$ and $P_{j}$ are the consumer price indices of country $i$ and $j$, respectively, and $\sigma$ denotes the elasticity of substitution between goods. The trade cost factor $t_{i j}$ captures all the costs of exporting goods from country $i$ to country $j$ such as transportation and information costs. The consumer price indices $P_{i}$ and $P_{j}$ are defined in terms of $t_{i j}$ as follows:

$$
\begin{aligned}
& P_{j}=\left[\sum_{i}\left(\beta_{i} p_{i} t_{i j}\right)^{(1-\sigma)}\right]^{\frac{1}{1-\sigma}} \\
& P_{i}=\left[\sum_{j}\left(\frac{t_{i j}}{P_{j}}\right)^{(1-\sigma)} \theta_{j}\right]^{\frac{1}{1-\sigma}}
\end{aligned}
$$

where $\beta_{i}$ is a positive distribution parameter, $p_{i}$ is country $i$ 's export price net of cross-border trade costs, and $\theta_{j}$ is country $j$ 's share in world GDP, that is $\theta_{j}=\frac{y_{j}}{y^{W}}$. Lower price indices imply lower trade costs with all countries. $P_{i}$ and $P_{j}$ therefore measure multilateral resistance as they capture how easily country $i$ and country $j$ trade with all countries. The price indices introduce substitutability in bilateral trade as they capture developments in the world market that affect bilateral trade between country $i$ and country $j$. Not accounting for third party trade developments would lead to erroneous attribution of all the effect of a trade barrier on bilateral trade, to developments between countries $i$ and $j$.

Equation (1) states that exports from country $i$ to country $j$ increase with an increase in total production of country $i$ (proxied by $y_{i}$ ) and with an increase in the total expenditure of country $j$ (proxied by $y_{j}$ ). The flow of goods from country $i$ to country $j$ is however moderated by a higher value of world output (proxied by $y^{W}$ ). On the other hand, the bilateral trade flow declines with an increase in bilateral trade costs $t_{i j}$, a reduction in the multilateral resistance of the two countries (proxied by $P_{i} P_{j}$ ), and with an increase in the sensitivity of consumers to the relative price of goods (captured by $\sigma$ ).

A merit of this framework is that it accounts for pure trade costs separately from production and consumption patterns of goods. However, there are practical challenges with implementing Equation (1) empirically. First, the bilateral trade costs term $\left(t_{i j}\right)$ is not readily measurable since not all trade costs can be observed and those that are observable have data limitations. The multilateral resistance terms are also difficult to measure as price indices only reflect costs that are paid for using money (Anderson and van Wincoop 2003). Third, estimates of elasticity of substitution $(\sigma)$ are sensitive to the level of aggregation of trade flows. The practice in the literature is to use time-varying, country-specific fixed effects to 
proxy the multilateral resistance terms (Feenstra 2004) or to reorganize the gravity equation and replace the terms with more readily measurable controls. The latter approach is the one adopted in Chen and Novy (2011).

Chen and Novy (2011) explore the size and sources of bilateral trade costs across countrypairs and industries of the European Union (EU) using a single measure of trade costs. The single measure of trade costs captures external trade costs relative to domestic trade costs. This measure is derived from the gravity model of Anderson and van Wincoop (2004), which is the industry-level version of the gravity model (Equation (1)) presented in Anderson and van Wincoop (2003). The move from the aggregate to the disaggregated gravity equation is permitted by "trade separability," meaning that an industry's production of and expenditure on a good can be determined independently of the prices of goods from other industries (Anderson and van Wincoop 2004). The method used to calculate the industry-specific elasticity of substitution parameter that is required in the gravity equation follows Imbs and Mejean (2009), Feenstra (1994), and Broda and Weinstein (2006).

To obtain the formula for calculating the single trade costs measure, Chen and Novy (2011) multiply an industry-level version of Equation (1) with a corresponding equation for the exports of industry $k$ goods from country $j$ to country $i$ to get the following equation:

$$
x_{i j}^{k} x_{j i}^{k}=\frac{y_{i}^{k} y_{j}^{k} y_{j}^{k} y_{i}^{k}}{y^{k} y^{k}}\left(\frac{t_{i j}^{k} t_{j i}^{k}}{P_{i}^{k} P_{j}^{k} P_{j}^{k} P_{i}^{k}}\right)^{1-\sigma_{k}}
$$

where $x_{i j}^{k}$ denotes nominal exports from country $i$ to country $j$ in industry $k$ goods, $x_{j i}^{k}$ denotes nominal exports from country $j$ to country $i$ in industry $k$ goods, $y_{i}^{k}, y_{j}^{k}$, and $y^{k}$ respectively denote output of industry $k$ goods from country $i$, country $j$ and the world, $t_{i j}^{k}$ and $t_{j i}^{k}$ are bilateral trade cost factors specific to industry $k$ goods, and $\sigma_{k}$ denotes the elasticity of substitution for industry $k$.

The gravity equation for domestic trade in country $i$ in industry $k$ goods is defined as follows:

$$
x_{i i}^{k}=\frac{y_{i}^{k} y_{i}^{k}}{y^{k}}\left(\frac{t_{i i}^{k}}{P_{i}^{k} P_{i}^{k}}\right)^{1-\sigma_{k}}
$$

where $t_{i i}^{k}$ denotes the cost of trading in industry $k$ goods within country $i$. Equation (2.2a) is rearranged to obtain the following expression:

$$
P_{i}^{k} P_{i}^{k}=\left(\frac{y_{i}^{k} y_{i}^{k}}{x_{i i}^{k} y^{k}}\right)^{1-\sigma_{k}} \cdot t_{i i}^{k}
$$

In Equation (2.2b), the difficult to measure multilateral resistance terms $P_{i}^{k}$ and $P_{j}^{k}$, are expressed as a function of expenditure shares and trade costs. This is because domestic trade increases with multilateral resistance. Equation (2.2b) and the analogous one for country $j$ are substituted into Equation (2) to obtain the following expression: 


$$
\frac{x_{i j}^{k} x_{j i}^{k}}{x_{i i}^{k} x_{j j}^{k}}=\left(\frac{t_{i j}^{k} t_{j i}^{k}}{t_{i i}^{k} t_{j j}^{k}}\right)^{1-\sigma_{k}}
$$

To avoid making assumptions about whether or not trade cost factors $t_{i j}^{k}$ and $t_{j i}^{k}$ are asymmetric (Chen and Novy 2011, p. 208), the square root of Equation (2.2c) is taken to obtain a measure of average bilateral relative trade barrier (or the inverse of bilateral trade integration) between country $i$ and country $j$ for industry $k$, denoted by $\theta_{i j}^{k}$, as follows:

$$
\theta_{i j}^{k}=\left(\frac{t_{i j}^{k} t_{j i}^{k}}{t_{i i}^{k} t_{j j}^{k}}\right)^{\frac{1}{2}}=\left(\frac{x_{i i}^{k} x_{j j}^{k}}{x_{i j}^{k} x_{j i}^{k}}\right)^{\frac{1}{2\left(\sigma_{k}-1\right)}}
$$

The total bilateral trade costs measure $\theta_{i j}^{k}$ is higher if the value of domestic trade in industry $k$ goods in either country $i$ or $j$ is larger than the value of trade in the goods between the two countries, which implies that cross-border trade costs are higher than domestic trade costs. Additionally, the less sensitive consumers are to the relative prices of industry $k$ goods ( $\sigma_{k}$ is low), the higher the cross-border trade costs are likely to be. Equation (3) is used in this paper to estimate total bilateral trade costs between EAC countries and their trade partners for 16 manufacturing industries over the period 1990 2012. The method is appealing because it permits the use of disaggregated data on production and exports and is easy to implement.

In this paper, Equation (3) is used to calculate total bilateral trade costs variable $\theta_{i j}^{k}$ as follows: for each year in the sample period, domestic trade variables $x_{i i}^{k}$ and $x_{j j}^{k}$ are first calculated as domestic production of industry $k$ goods minus exports of industry $k$ goods to the rest of the world by each of the producing countries $i$ and $j$. Domestic production is measured in US dollars and the data is obtained from the INDSTAT2 online database. Data on exports to the rest of the world is also measured in US dollars and is obtained from the COMTRADE online database. The two domestic trade variables are then multiplied together and divided by the product of the value of unidirectional trade between country $i$ and country $j$ for industry $k$, denoted by $x_{i j}^{k} x_{j i}^{k}$, where $x_{i j}^{k}$ is the US dollar F.O.B value of exports of industry $k$ goods from country $i$ to country $j, x_{j i}^{k}$ is the US dollar F.O.B value of exports of industry $k$ goods from country $j$ to country $i$. This trade data is obtained from COMTRADE. The geometric mean of the ratio between the domestic and international trade variables is then calculated, weighted by the elasticity of substitution parameter $\sigma_{k}$, according to Equation (3). The derivation of the elasticity of substitution parameter is outlined in the following subsection.

\section{B. Estimating the elasticity of substitution parameter}

In this paper, the elasticity of substitution parameter $\sigma_{k}$ in Equation (3) is estimated from data on imports of manufactured goods into EAC countries using the method developed in Feenstra (1994). The method considers that a change in the availability of varieties of goods may upwardly bias price elasticities estimated from supply-demand equations by overstating 
the share of expenditure on any variety. The price of a variety of a good is expected to be lower in a market that has a wider range of similar varieties. The method accounts for the disappearing of old and the supply of new varieties that are imported into a market by incorporating their appearance and disappearance directly into the import price index.

The formula for estimating the elasticity of substitution parameter from data on imports in Feenstra (1994) is derived by the minimum cost of acquiring one unit of services from a set of varieties $i$, denoted by $c$ which is defined as follows:

$$
c\left(\mathbf{p}_{t}, \mathbf{I}_{t}, \mathbf{b}_{t}\right)=\left(\sum_{i \in \mathbf{I}_{t}} b_{i, t} p_{i, t}^{1-\sigma}\right)^{\frac{1}{1-\sigma}}, \quad \sigma>1
$$

where $p_{i, t}$ is the price of variety $i$ that is available in period $t, \mathbf{I}_{t}$ is the set of varieties that is available in period $t, b_{i, t}$ is a positive taste parameter for variety $i, \sigma$ is the elasticity of substitution, $\mathbf{p}_{t}$ is the vector of prices in period $t$, and $\mathbf{b}_{t}$ is the vector of taste parameters in period $t$. Assuming the set of available varieties $\mathbf{I}_{t}$ is the same in periods $t-1$ and $t$ and the taste parameters $b_{i, t}$ are constant for $i \in \mathbf{I}$, the exact price index may be defined as follows:

$$
P\left(\boldsymbol{p}_{t-1}, \boldsymbol{p}_{t}, \boldsymbol{x}_{t-1} \boldsymbol{x}_{t}, \boldsymbol{I}\right)=\frac{c\left(\boldsymbol{p}_{t}, \boldsymbol{I}, \boldsymbol{b}\right)}{c\left(\boldsymbol{p}_{t-1}, \boldsymbol{I}, \boldsymbol{b}\right)}
$$

where $\mathbf{x}_{t-1}$ and $\mathbf{x}_{t}$ are cost-minimizing quantity vectors given prices $\mathbf{p}_{t-1}$ and $\mathbf{p}_{t}$.

In the case of a change in the set of available varieties $\mathbf{I}_{t}$ and a change in the taste parameters $\mathbf{b}_{i, t}$ between periods $t-1$ and $t$, the conventional price index $P(\cdot)$, which is measured on observed prices and quantities, may be adjusted to obtain the exact price index which is now denoted by $\pi(\cdot)$ as follows:

$$
\frac{c\left(\mathbf{p}_{t}, \mathbf{I}_{t}, \mathbf{b}_{t}\right)}{c\left(\mathbf{p}_{t-1}, \mathbf{I}_{t-1}, \mathbf{b}_{t-1}\right)}=\pi\left(\mathbf{p}_{t-1}, \mathbf{p}_{t}, \mathbf{x}_{t-1}, \mathbf{x}_{t}, \mathbf{I}\right) \equiv P\left(\mathbf{p}_{t-1}, \mathbf{p}_{t}, \mathbf{x}_{t-1}, \mathbf{x}_{t}, \mathbf{I}\right)\left(\frac{\lambda_{t}}{\lambda_{t-1}}\right)^{\frac{1}{\sigma-1}}
$$

where

$$
\lambda_{r} \equiv \frac{\sum_{i \in I} p_{i, r} x_{i, r}}{\sum_{i \in I_{r}} p_{i, r} x_{i, r}}, \quad \text { for } r=t-1, t
$$

and $I$ denotes the set of varieties that is available in periods $t-1$ and $t$.

From Equation (6), an increase in the share of expenditure on newly available varieties will lower $\lambda_{t}$ and lower the exact price index $\pi(\cdot)$ relative to the conventional price index $P(\cdot)$. However, an increase in $\sigma$ will lower $\frac{1}{\sigma-1}$ and bring $\pi(\cdot)$ closer to $P(\cdot)$ indicating a smaller impact of new varieties on unit costs.

For the case of imports from a country $i$ in which a number of varieties are produced, the cost of obtaining a unit of import services is defined as follows: 


$$
c\left(\boldsymbol{\pi}_{t}, \mathbf{I}_{t}, \mathbf{b}_{t}\right)=\left(\sum_{i \in I_{t}} b_{i, t} \pi_{i, t}^{1-\sigma}\right)^{\frac{1}{1-\sigma}}=\left(\sum_{i \in I_{t}} b_{i, t} \frac{\lambda_{i, t}}{\lambda_{i, t-1}} P_{i, t}^{1-\sigma}\right)^{\frac{1}{1-\sigma}}
$$

where $\pi_{i, t}$ is the exact price index of varieties imported from country $i$ defined as $\pi_{i, t}=P_{i, t}\left(\lambda_{i, t} /\right.$ $\left.\lambda_{i, t-1}\right)^{1 /(\sigma-1)}$ according to Equation (6), and $b_{i, t}$ is the taste parameter for the imports from country $i$. The share of expenditure on imports from country $i$, denoted by $s_{i, t}$, (or the demand curve for the variety) is then defined as follows:

$$
s_{i, t}=c\left(\boldsymbol{\pi}_{t}, \mathbf{I}_{t}, \mathbf{b}_{t}\right)^{\sigma-1} \times P_{i, t}^{-(\sigma-1)}\left(b_{i, t} \frac{\lambda_{i, t-1}}{\lambda_{i, t}}\right)
$$

where $s_{i, t}$ increases with the number of varieties available from country $i$, which in turn would be reflected in a lower value of $\lambda_{i, t}$. Equation (8) may be written in first-differenced log form as:

$$
\Delta \ln s_{i, t}=\emptyset_{t}-(\sigma-1) \Delta \ln P_{i, t}+\epsilon_{i, t}
$$

where

$$
\emptyset_{t} \equiv(\sigma-1) \ln \left(\mathrm{c}\left(\pi_{t}, \mathbf{I}_{t}, \mathbf{b}_{t}\right) / \mathrm{c}\left(\pi_{t-1}, \mathbf{I}_{t-1}, \mathbf{b}_{t-1}\right)\right)
$$

The supply curve for the imports from country $i$ is given as:

$$
\Delta \ln P_{i, t}=w \Delta \ln x_{i, t}+\xi_{i, t}
$$

where the quantity of imports from country $i$ (in terms of expenditure share) $x_{i, t} \equiv s_{i, t} E_{t} / P_{i, t} E_{t}$ is expenditure on an imported product, $\omega \geq 0$ is the inverse supply elasticity (assumed to be the same for all supplying countries), and $\xi_{i, t}$ does not depend on $\epsilon_{i, t}$

The equilibrium price, derived by combining the supply and demand curves of the imports from country $i$, is:

$$
\Delta \ln P_{i, t}=\psi_{t}+\rho \frac{\epsilon_{i, t}}{\sigma-1}+\delta_{i, t}
$$

where $0 \leq \rho<1$.

Equations (9) and (11) are differenced relative to a reference supplier country $k$ to eliminate $\varphi_{t}$ and $\psi_{t}$ and obtain equations:

$$
\tilde{\epsilon}_{i, t}=\epsilon_{i, t}-\epsilon_{k, t}=\left(\Delta \ln s_{i, t}-\Delta \ln s_{k, t}\right)+(\sigma-1)\left(\Delta \ln P_{i, t}-\Delta \ln P_{k, t}\right)
$$

and 


$$
\tilde{\delta}_{i, t}=\delta_{i, t}-\delta_{k, t}=(1-\rho)\left(\Delta \ln P_{i, t}-\Delta \ln P_{k, t}\right)-\frac{\rho}{\sigma-1}\left(\Delta \ln s_{i, t}-\Delta \ln s_{k, t}\right)
$$

which are then multiplied together and divided by $(1-\rho)(\sigma-1)>0$ to get:

$$
Y_{i, t}=\theta_{1} X_{1 i, t}+\theta_{2} X_{2 i, t}+u_{i, t}
$$

where

$$
\begin{gathered}
Y_{i, t}=\left(\Delta \ln P_{i, t}-\Delta \ln P_{k, t}\right)^{2} \\
X_{1 i, t}=\left(\Delta \ln s_{i, t}-\Delta \ln s_{k, t}\right)^{2} \\
X_{2 i, t}=\left(\Delta \ln s_{i, t}-\Delta \ln s_{k, t}\right)\left(\Delta \ln P_{i, t}-\Delta \ln P_{k, t}\right) \\
\theta_{1}=\frac{\rho}{(\sigma-1)^{2}(1-\rho)} \\
\theta_{1}=\frac{(2 \rho-1)}{(\sigma-1)(1-\rho)} \\
u_{i, t}=\frac{\tilde{\epsilon}_{i, t} \widetilde{\delta}_{i, t}}{(1-\rho)(\sigma-1)}
\end{gathered}
$$

Variables $X_{1 i, t}$ and $X_{2 i, t}$ are endogenous in Equation (14). This problem is addressed by averaging $Y_{i, t}, X_{1 i, t}$, and $X_{2 i, t}$ over the sample period so that the equation estimated for each imported variety $i$ is:

$$
\bar{Y}_{i}=\theta_{0}+\theta_{1} \bar{X}_{1 i}+\theta_{2} \bar{X}_{2 i}+\bar{u}_{i, t}
$$

The constant term $\theta_{0}$ is included in Equation (15) to capture the variance of the measurement error, which arises from the use of unit values instead of actual import prices. The estimated coefficients $\hat{\theta}_{1}$ and $\hat{\theta}_{2}$ are used to calculate the elasticity of substitution $\sigma$ using the following formula (derived from Equations (14d) and (14e)):

$$
\hat{\sigma}=1+\left(\frac{2 \widehat{\rho}-1}{1-\widehat{\rho}}\right) \frac{1}{\hat{\theta}_{2}}>1
$$

where

$$
\hat{\rho}=\frac{1}{2}+\left(\frac{1}{4}-\frac{1}{4+\frac{\hat{\theta}_{2}^{2}}{\hat{\theta}_{1}}}\right)^{\frac{1}{2}} \quad \text { if } \hat{\theta}_{2}>0
$$




$$
\hat{\rho}=\frac{1}{2}-\left(\frac{1}{4}-\frac{1}{4+\frac{\hat{\theta}_{2}^{2}}{\hat{\theta}_{1}}}\right)^{\frac{1}{2}} \quad \text { if } \hat{\theta}_{2}<0
$$

If $\hat{\theta}_{1}<0$, estimates will fall out of the ranges $\hat{\sigma}>1$ and $0 \leq \hat{\rho}<1$.

Equation (15) is implemented in this paper using import data for each of the 16 industries separately. I use data on the value of imports into five EAC countries (Burundi, Kenya, Rwanda, Tanzania, and Uganda) from 196 countries and territories (also including EAC countries to capture intra-EAC trade) for the period 1990 2012. The 196 countries and territories exported manufactured goods to at least one of the EAC countries, which is reported in COMTRADE. Weighted least squares is applied with $1 / T$ as weights. $T$ is the total number of years that a good was traded between two countries over the sample period. Price and expenditure shares that are averaged over a longer period of time are assigned larger weights (Feenstra 1991).

Unit values of imported goods are used to calculate price differentials according to Equation (14a). The US dollar C.I.F values of imported goods are used to calculate expenditure share differentials according to Equation (14b). For each EAC country, the dominant (or reference) supplier per ISIC category is identified as the country that exported the most to the EAC country in US dollar value terms in all years of the study period. For instance, Kenya and Tanzania imported food and beverages predominantly from Indonesia, while China was the dominant supplier of textiles and furniture to Burundi, Rwanda, Tanzania, and Uganda. India was the dominant supplier of chemicals and chemical products to all EAC countries while Japan supplied most motor vehicles and trailers to the region. The full list of dominant suppliers by EAC country and ISIC category is provided in Appendix 4.

The price and expenditure share differentials for each of the EAC countries in each industry are pooled when estimating Equation (15) to obtain average elasticity of substitution estimates for each of the 16 industries for the entire EAC market. It is shown in Section 7 of this paper that the total bilateral trade costs estimates become too large when the elasticity of substitution parameter can vary by both industry and country. I therefore opt to derive the elasticities for each industry separately but common for all EAC countries. The estimated coefficients $\hat{\theta}_{1}$ and $\hat{\theta}_{2}$ are then used to calculate the elasticities of substitution for each industry using Equation (16). I do not calculate the elasticity of substitution when $\hat{\theta}_{1}<0$ since $\hat{\rho}$ would fall out of the range $[0,1]$ and $\hat{\sigma}<1$. The elasticity of substitution for each industry (ISIC category) are reported in Table 1. The estimates range from 3 to 14 with a mean of 7 and a standard deviation of 3 . The estimates in Chen and Novy (2011) for the EU also average to 7. Anderson and van Wincoop (2004, p. 716) suggest, based on evidence in the literature, that the elasticity of substitution parameter would be between 5 and 10 , implying an average of 7.5. 


\section{Table 1. Elasticity of substitution estimates by ISIC category, averaged across EAC countries}

\begin{tabular}{|c|c|c|c|c|c|c|}
\hline ISIC code and description & $\hat{\theta}_{0}$ & $\hat{\theta}_{1}$ & $\hat{\theta}_{2}$ & $\hat{\rho}$ & $\hat{\sigma}$ & $\begin{array}{l}\hat{\sigma} \text { for the } E U \\
\text { from Chen } \\
\text { and Novy } \\
(2011)\end{array}$ \\
\hline 15 Food and beverages & $\begin{array}{c}0.99 \\
(0.14)\end{array}$ & $\begin{array}{c}0.11 \\
(0.03)\end{array}$ & $\begin{array}{c}0.30 \\
(0.13)\end{array}$ & 0.7 & 6 & 7 \\
\hline 16 Tobacco products & $\begin{array}{l}1.75 \\
(0.51)\end{array}$ & $\begin{array}{c}0.06 \\
(0.06) \\
-\end{array}$ & $\begin{array}{c}0.56 \\
(0.21)\end{array}$ & 0.9 & 13 & 8 \\
\hline 17 Textiles & $\begin{array}{c}1.50 \\
(0.19)\end{array}$ & 0.11 & $\begin{array}{c}0.63 \\
(0.21)\end{array}$ & 0.9 & 8 & 6 \\
\hline 18 Wearing apparel, fur & $\begin{array}{l}1.58 \\
(0.19)\end{array}$ & 0.12 & $\begin{array}{c}0.60 \\
(0.17)\end{array}$ & 0.8 & 7 & 8 \\
\hline $\begin{array}{l}19 \text { Leather, leather } \\
\text { products and footwear }\end{array}$ & $\begin{array}{c}1.55 \\
(0.50)\end{array}$ & $\begin{array}{c}0.26 \\
(0.13)\end{array}$ & $\begin{array}{c}0.85 \\
(0.23)\end{array}$ & 0.8 & 5 & 9 \\
\hline $\begin{array}{l}20 \text { Wood products } \\
\text { (excl. furniture) }\end{array}$ & $\begin{array}{c}1.69 \\
(0.31)\end{array}$ & 0.18 & $\begin{array}{c}0.33 \\
(0.15)\end{array}$ & 0.7 & 4 & 5 \\
\hline $\begin{array}{l}21 \text { Paper and paper } \\
\text { products }\end{array}$ & $\begin{array}{c}0.93 \\
-0.14)\end{array}$ & 0.18 & $\begin{array}{c}0.18 \\
(0.11)\end{array}$ & 0.6 & 4 & 6 \\
\hline 22 Printing and publishing & $\begin{array}{c}1.48 \\
(0.16)\end{array}$ & 0.09 & $\begin{array}{c}0.78 \\
(0.08)\end{array}$ & 0.9 & 11 & 5 \\
\hline $\begin{array}{l}23 \text { Coke, refined petroleum } \\
\text { products, nuclear fuel }\end{array}$ & $\begin{array}{l}1.35 \\
(0.21)\end{array}$ & $\begin{array}{c}0.01 \\
(0.02)\end{array}$ & $\begin{array}{l}-0.41 \\
(0.16)\end{array}$ & 0.1 & 3 & - \\
\hline $\begin{array}{l}24 \text { Chemicals and } \\
\text { chemical products }\end{array}$ & $\begin{array}{c}2.33 \\
(0.28)\end{array}$ & $\begin{array}{c}0.15 \\
(0.06)\end{array}$ & $\begin{array}{c}0.54 \\
(0.24)\end{array}$ & 0.8 & 6 & 8 \\
\hline $\begin{array}{l}25 \text { Rubber and plastics } \\
\text { products }\end{array}$ & $\begin{array}{l}1.45 \\
(0.20)\end{array}$ & $(0.04)$ & $(0.56$ & 0.8 & 8 & 6 \\
\hline $\begin{array}{l}26 \text { Non-metallic mineral } \\
\text { products }\end{array}$ & $\begin{array}{l}1.58 \\
(0.20)\end{array}$ & 0.13 & $(0.16)$ & 0.3 & 3 & 4 \\
\hline 27 Basic metals & $\begin{array}{c}1.43 \\
(0.27)\end{array}$ & $\begin{array}{c}0.11 \\
-(0.05)\end{array}$ & $\begin{array}{c}0.66 \\
-(0.28)\end{array}$ & 0.9 & 9 & 4 \\
\hline $\begin{array}{l}29 \text { Machinery and } \\
\text { equipment n.e.c. }\end{array}$ & $\begin{array}{l}1.36 \\
(0.21)\end{array}$ & $\begin{array}{c}0.09 \\
(0.04)\end{array}$ & $\begin{array}{c}1.02 \\
(0.22)\end{array}$ & 0.9 & 14 & 12 \\
\hline $\begin{array}{l}34 \text { Motor vehicles, trailers, } \\
\text { semi-trailers }\end{array}$ & $\begin{array}{l}1.62 \\
(0.16)\end{array}$ & $(0.15$ & $\begin{array}{c}0.42 \\
(0.21)\end{array}$ & 0.7 & 5 & 10 \\
\hline $\begin{array}{l}36 \text { Furniture; } \\
\text { manufacturing n.e.c. }\end{array}$ & $\begin{array}{c}1.21 \\
(0.16) \\
\end{array}$ & $\begin{array}{c}0.20 \\
(0.06)\end{array}$ & $\begin{array}{c}0.47 \\
(0.17) \\
\end{array}$ & 0.7 & 5 & 6 \\
\hline \multicolumn{5}{|c|}{$\begin{array}{l}\text { Spearman's rank correlation coefficient between EAC and } \\
\text { EU estimates }\end{array}$} & 0.20 & \\
\hline
\end{tabular}

(Note) I report the Spearman's rank correlation coefficient because it is not sensitive to outliers. Standard Errors are in Parentheses

(Source) Author's calculations based on data from COMTRADE online database. 
Non-metallic mineral products (ISIC 26) and fuel products (ISIC 23) have the lowest elasticity of substitution of three, implying that they are the least price-sensitive of the manufactured products traded by the EAC (Table 1). Paper and wood products have an elasticity of substitution of four while furniture, leather products and motor vehicles and trailers have an elasticity of substitution of five. Goods classified as food and beverages, chemicals, rubber, plastics, textiles and basic metals have relatively higher elasticities ranging from six to nine. Goods categorized under printing and publishing, tobacco products, and machinery and equipment are the most substitutable of the imported goods with elasticity of substitution estimates that are higher than 10 .

The estimates of $\hat{\theta}_{1}$ and $\hat{\theta}_{2}$ in Table 1 imply that price differentials respond negatively to an increase in expenditure share differentials for non-metallic mineral products and fuel products, meaning that a supplier increasing their import share relative to the dominant supplier has slower price adjustment relative to the dominant supplier. The relationship between price and expenditure share differentials is positive for the other industries, and strongest for machinery and equipment, leather products, and printing and publishing. Measurement errors are important for all ISIC categories as the constant term is statistically significant.

The last column of Table 1 shows simple averages of elasticity of substitution estimates for 11 countries of the EU, which are reported in Chen and Novy (2011). The EAC and EU estimates are in the range of 3 to 14 but are poorly correlated (the Spearman's rank correlation coefficient is 0.20 ). Consumers in the EAC market are comparably more sensitive to the relative prices of tobacco products, printing and publishing, and basic metals, and comparably less sensitive to the relative prices of motor vehicles and leather products. This points to a difference in consumer expenditure patterns in the two markets, and indicates the appropriateness of estimating, for the purposes of this study, the elasticity of substitution parameter for the EAC.

\section{Estimates of Total Bilateral Trade Costs}

For the remainder of this paper and for ease of exposition, I refer to an EAC country as "exporter" and their trade partner as "importer," where the importer can either be an EAC country or a non-EAC country. Note however that the total bilateral trade costs are estimated from two-way trade flow data.

For each year in the period 1990 2012, total bilateral trade costs with respect to each exporter-importer-industry triple are calculated using Equation (3), where $x_{i j}^{k}$ is the US dollar F.O.B value of exports of industry $k$ goods from exporter $i$ to importer $j, x_{j i}^{k}$ is the US dollar F.O.B value of exports of industry $k$ goods from importer $j$ to exporter $i, x_{i i}^{k}$ and $x_{j j}^{k}$ are the US dollar values of domestic trade in industry $k$ goods in exporter $i$ and importer $j$, respectively. Domestic trade is calculated as domestic production minus exports to the rest of the world by the producing country. The elasticity of substitution parameter for each industry $\sigma_{k}$ is as reported in Table 1. 
A total of 11,095 bilateral trade costs estimates are generated from the data. The estimates range from 1.03 to $14,825.91$ with a mean of 55.81 and a standard deviation of 383.24 . The estimates of total bilateral trade costs for each exporter, averaged over the sample period 1990 2012 and across the importers are presented in Table 2. A more detailed summary of the estimates is provided in Appendix 5. 


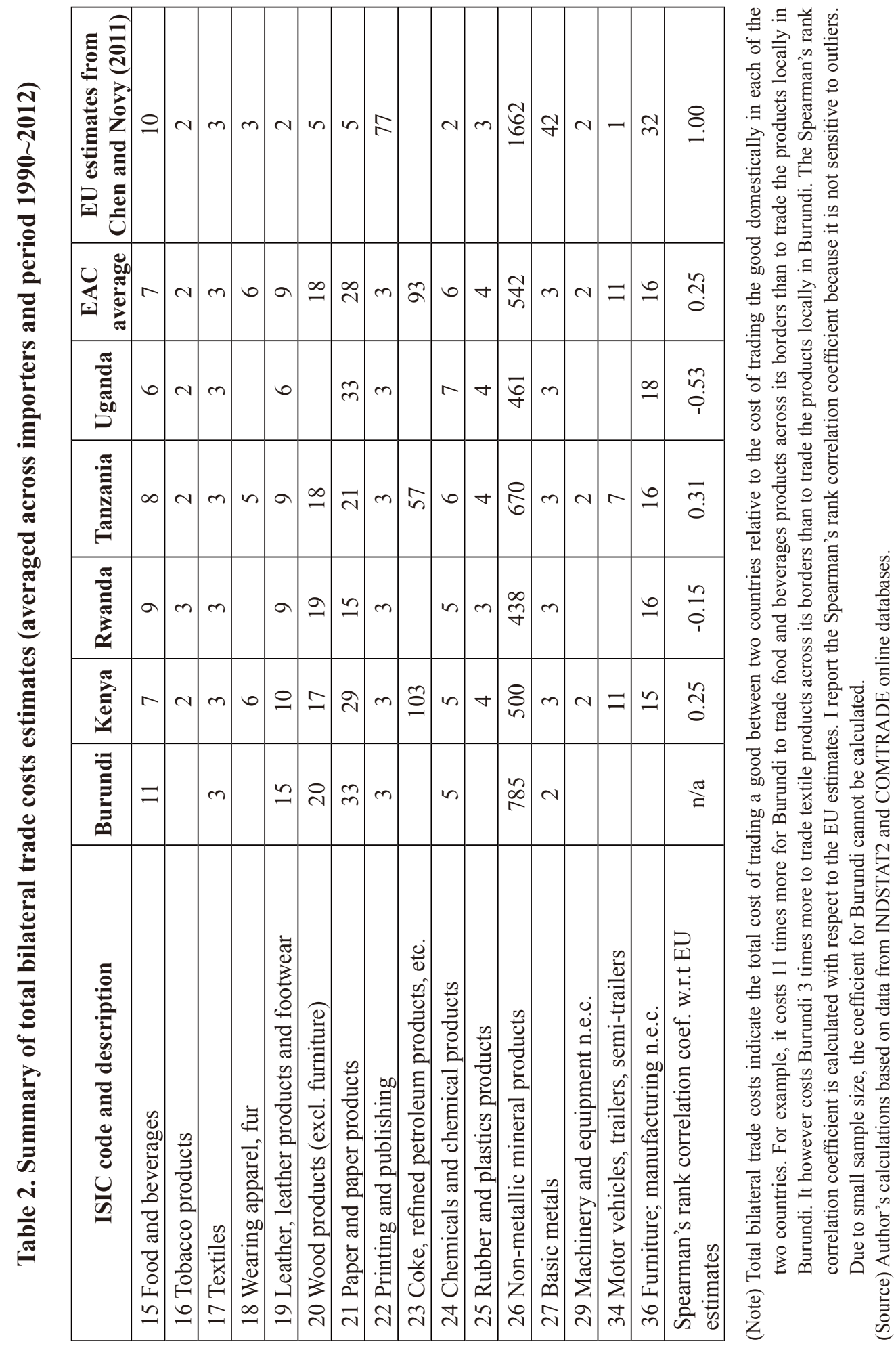


To see the distribution of total bilateral trade costs across country-pairs, I average the estimates across industries and across the exporters for each importer and map this in Figure 4. The map shows that total bilateral trade costs are lowest with respect to importers that are located closer to the EAC and those along the rim of the Indian Ocean. Total bilateral trade costs are also lower with respect to the former EAC colonizer, the United Kingdom. These geographical characteristics are potential determinants of EAC total bilateral trade costs.

\section{Figure 4. Map of total bilateral trade costs, averaged across EAC countries and industries}

(Excluding 2 Outlier Industries)

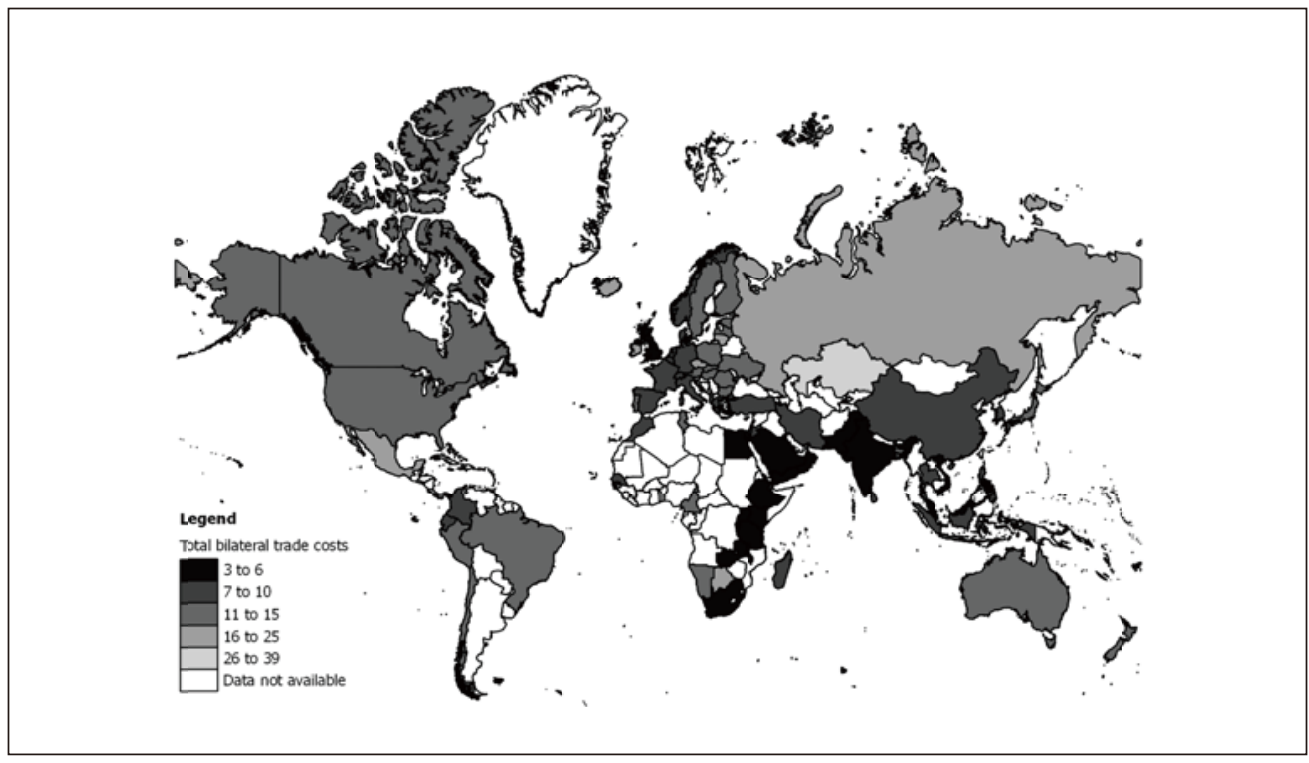

(Note) The map reads as follows, for example: EAC countries find it 3 to 6 times more expensive to trade goods with the countries coloured in black than to trade the goods domestically within each EAC country. Data is not available for countries marked in white. Industries manufacturing fuel products (ISIC 23) and non-metallic mineral products (ISIC 26) have very high trade costs and are excluded from the map.

(Source) Author's calculations based on data from INDSTAT2 and COMTRADE online databases.

Comparing trends across importers, it costs on average about three times more to trade manufactured goods between EAC and non-EAC countries than to trade manufactured goods within the EAC (shown in Figure 5). Over time, intra-EAC total bilateral trade costs show a downward trend while extra-EAC total bilateral trade costs show an upward trend. The divergence in the trends starts in 2000, which is the year after the EAC Treaty was signed. Trade policy measures implemented under the EAC Treaty are therefore potential determinants of the total bilateral trade costs. Aside from changes in international trade costs, it is possible that the time trend in the total bilateral trade costs estimates reflects changes in domestic trade costs both within and outside the EAC. 
In terms of the distribution of the estimates across industries, the total bilateral trade costs are on average lower for machinery and equipment, tobacco products, printing and publishing, basic metals, textiles, and rubber and plastics products. It costs between two to four times more to trade these products across EAC country borders than to trade the products within each EAC country (see Table 2). External bilateral trade costs are on average 20 times more than domestic trade costs for paper products, wood products, and furniture. More restrictive external bilateral trade costs are implied for non-metallic mineral products and fuel products. By definition, these estimates correlate negatively with the corresponding elasticity of substitution estimates.

A difference across the industries, which matters for trade costs and for which data is available, is import tariff rates. The import tariff rates for the exporters are averaged across country-pairs and years and then related to the similarly averaged logarithm of total bilateral trade costs in a scatterplot shown in the left panel of Figure 6. The median import tariff rate is 18.6. Figure 6 shows that industries facing tariff rates above 18.6 also tend to have comparably higher total bilateral trade costs. This indicates that the import tariff rate is one of the determinants of the distribution of total bilateral trade costs across industries.

\section{Figure 5. Trends in total bilateral trade costs}

(Excludes ISIC 23 and ISIC 26, 1990 2012)

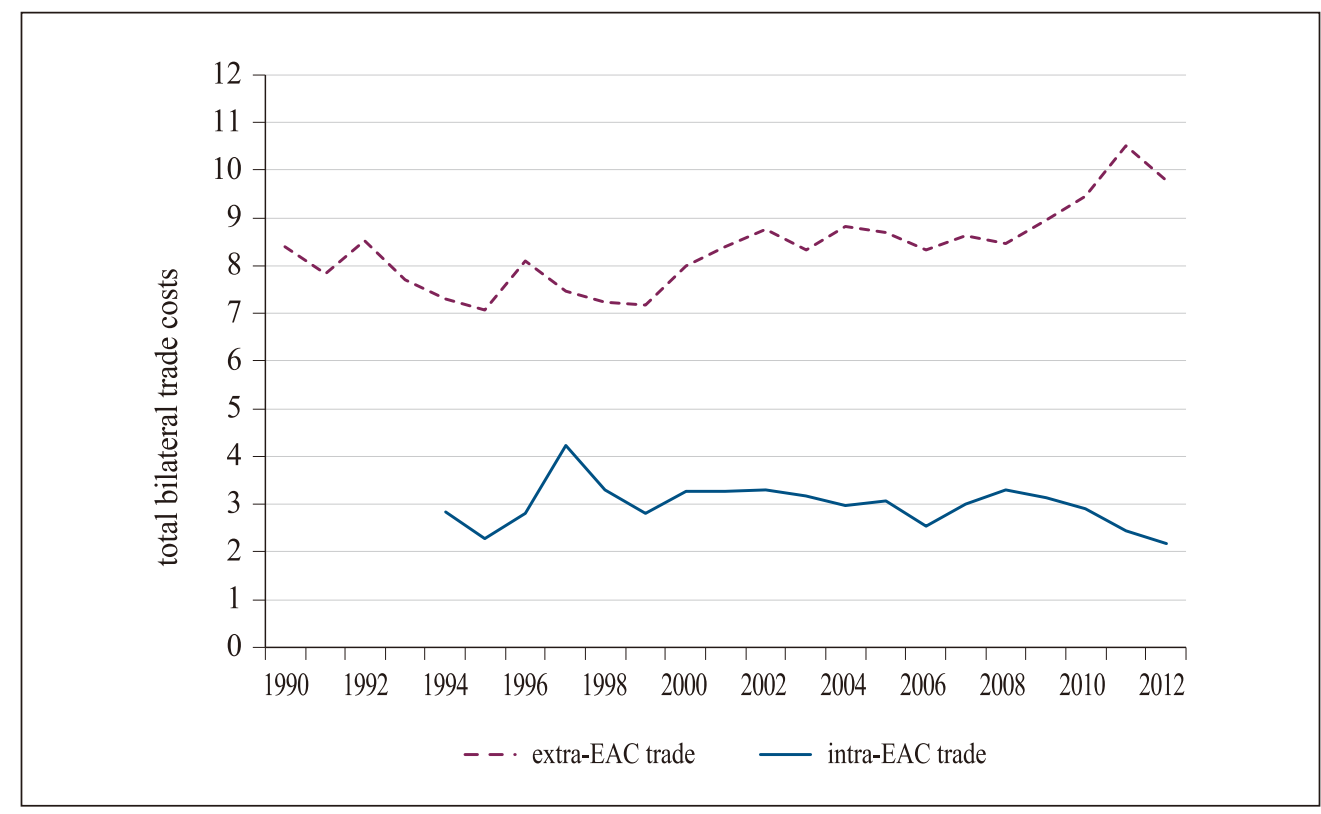

(Note) Total bilateral trade costs indicate the total cost of trading a good between two countries relative to the cost of trading the good domestically in each of the two countries. Extra-EAC trade refers to trade between an EAC country and a non-EAC country. Intra-EAC trade refers to trade between two EAC countries. Industries manufacturing fuel products (ISIC 23) and non-metallic mineral products (ISIC 26) have very high trade costs and are excluded from the figure.

(Source) Author's calculations based on data from INDSTAT2 and COMTRADE online databases. 
Another distinguishing characteristic of industries that is observable and easily measurable is the weight-to-value ratio of goods. The weight of goods matters for the cost of transporting them over distance (Chen 2004, Head and Mayer 2002). For each industry, weight-to-value ratios are calculated from imports data that has been averaged across country-pairs and years in the sample. The ratios are then related to the logarithm of total bilateral trade costs, which is also averaged across country-pairs and time, in a scatterplot shown in the right panel of Figure 6. The scatterplot shows that non-metallic mineral products (ISIC code 26) have the highest weight-to-value ratio at 6.5 compared with the median of 0.5 for all industries. This industry also has the highest total bilateral trade costs. Generally, there is a positive correlation between the weight-to-value ratios of industries and their total bilateral trade costs. Given this positive correlation, a potential determining factor of EAC total bilateral trade costs would be the quality of transportation infrastructure, which would determine the cost of transporting goods over distance. That the positive correlation between total bilateral trade costs and weight-to-value ratios appears to be stronger than the correlation between the trade costs and import tariff rates indicates a larger role for transportation infrastructure in determining the distribution of trade costs across industries.

\section{Figure 6. Scatter plot of total bilateral trade costs versus import tariff rates and weight-to-value ratios}

(averages across country-pairs and time)

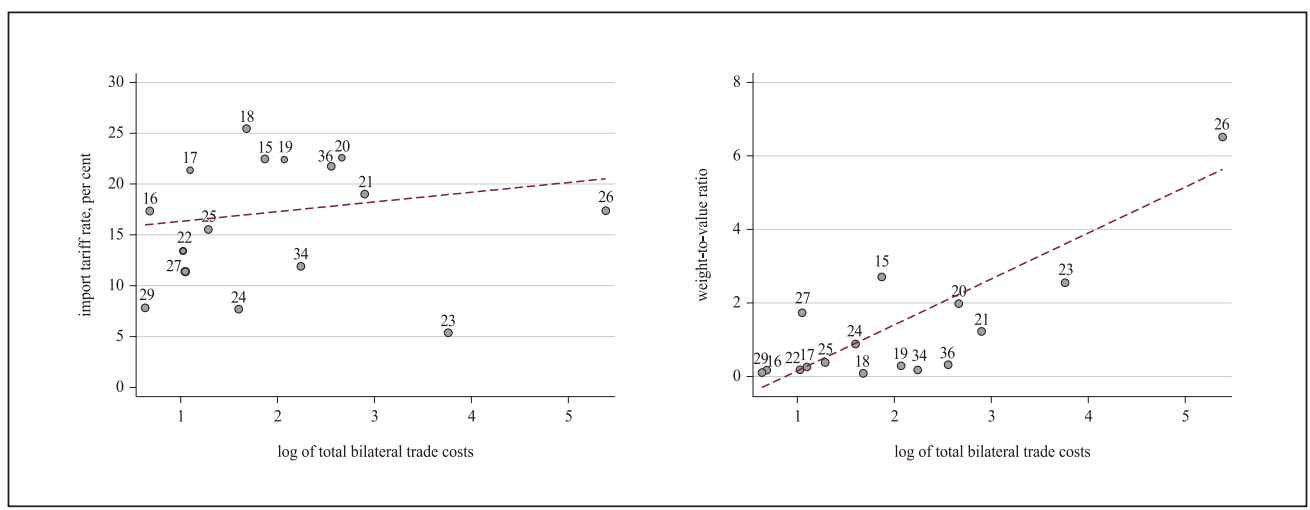

(Note) The numbers in the scatter plots indicate the ISIC codes of each industry. Total bilateral trade costs indicate the total cost of trading a good between two countries relative to the cost of trading the good domestically in each of the two countries. For each industry, import tariff rate is the simple average of the effectively applied tariff rates at the product level. For each industry, weight-to-value ratio is import volume divided by import value.

(Source) Author's calculations based on data from INDSTAT2, COMTRADE and WITS/TRAINS online databases.

The last column of Table 2 shows the simple averages of total bilateral trade costs for 11 countries of the EU, which are reported in Chen and Novy (2011). The EAC estimates are within range of the EU estimates but are weakly correlated as indicated by the Spearman's 
rank correlation coefficient. In comparison, both sets of estimates indicate costly external trade for non-metallic mineral products. However, it is comparably more expensive to trade paper products, wood products, and motor vehicles across EAC country borders than across EU country borders, and less expensive to trade furniture, basic metals, and print products across EAC country borders than across EU country borders. The differences between the EAC and EU estimates of total bilateral trade costs reflect the different elasticity of substitution parameters and may also reflect the comparably wider geographical distribution of non-EAC trade partners. The differences in the two sets of estimates could also reflect differences in trade policies pursued by the two trade blocs. The total bilateral trade costs estimates comprise both external and internal trade costs; it is not immediately known which of the two components drives the differences between the EAC and EU estimates.

In summary, this section presents estimates of total bilateral trade costs for the five EAC countries of interest in 16 industries, with respect to themselves and other 87 trade partners over the period 1990 2012. In terms of size, the estimates indicate that cross-border trade costs are on average 56 times larger than domestic trade costs (eight excluding two outlier industries), and that external trade costs increase with geographical distance from the EAC and being landlocked. The analysis in this section also suggests that trade policy may be a determinant of the trade costs. This is indicated by the coincidental decline in intra-EAC trade costs beginning in 2000 when the EAC Treaty came into force, as well as the positive correlation between the trade costs estimates and import tariff rates and product weight-tovalue ratios. The latter points to transportation costs and implies a role for the quality of transportation infrastructure in determining the distribution of total bilateral trade costs across industries.

\section{Determinants of Total Bilateral Trade Costs}

In this section, the estimates of total bilateral trade costs presented in Section 5 are analyzed in relation to a set of proxy variables for trade costs that is standard in the literature that uses the gravity equation. ${ }^{5}$ These proxy variables contain information about the potential determinants of total bilateral trade costs for the EAC, which are highlighted in the previous section (that is, geographical location, colonial history, and tariff and non-tariff policy measures). The model used in the analysis is of the following form:

$$
\ln \left(\text { Total bilateral trade costs } s_{i j k, t}\right)=\alpha+\beta X_{i j, t}+\delta_{i, t}+\delta_{j, t}+\delta_{k, t}+\epsilon_{i j k, t}
$$

where the natural logarithm of total bilateral trade costs between exporter $i$ and importer $j$ for industry $k$ at time $t$ is regressed on a constant, $\alpha$, a set of trade cost proxy variables, $X_{i j, t}$ , exporter-year fixed effects, $\delta_{i, t}$, importer-year fixed effects, $\delta_{j, t}$ and industry-year fixed effects, $\delta_{k, t} \cdot \epsilon_{i j k, t}$ is the error term. To account for correlation of errors within country

${ }^{5}$ For example French (2016), Bergstrand et al. (2015), Egger and Sergey (2015), Chen and Novy (2011), Jacks et al. (2011), Vicard (2011), Baier and Bergstrand (2009), Helpman et al. (2008), Silva and Tenreyro (2006), Rose (2004). 
groups, I cluster and report standard errors at the country-pair level.

The trade cost proxy variables are the natural logarithm of the geographical distance between country-pair $i j$, and indicator variables for a common border, same official language, common colonizer, landlocked countries, and existence of a trade agreement between the countries in the pair. These variables give indication of how close the trading pair is in geographical, cultural, and political terms. Total bilateral trade costs are expected to be lower for a country-pair that is geographically closer and are more familiar with each other. The trade cost proxy variables included in Equation (17) are as described in Table 3.

\section{Table 3. Description of trade cost proxy variables}

\begin{tabular}{|l|l|}
\hline \multicolumn{1}{|c|}{ Variable } & \multicolumn{1}{c|}{ Description } \\
\hline Bilateral distance & $\begin{array}{l}\text { Great-circle distance (in kilometres) between the most populated } \\
\text { cities in the respective trading countries }\end{array}$ \\
\hline Common border & $\begin{array}{l}\text { Indicator variable equal to } 1 \text { if the trading pair share a common } \\
\text { border and } 0 \text { otherwise }\end{array}$ \\
\hline $\begin{array}{l}\text { Common language } \\
\text { (official) }\end{array}$ & $\begin{array}{l}\text { Indicator variable equal to } 1 \text { if the trading pair have the same official } \\
\text { language and } 0 \text { otherwise }\end{array}$ \\
\hline Common colonizer & $\begin{array}{l}\text { Indicator variable equal to } 1 \text { if the trading pair were the colonies of } \\
\text { the same third country after } 1945 \text { and } 0 \text { otherwise }\end{array}$ \\
\hline Landlocked & $\begin{array}{l}\text { Indicator variable equal to } 1 \text { if both countries in the trading pair are } \\
\text { landlocked and } 1 \text { otherwise }\end{array}$ \\
\hline EAC membership & $\begin{array}{l}\text { Indicator variable equal to } 1 \text { if both countries in the trading pair are } \\
\text { members of the EAC and } 0 \text { otherwise }\end{array}$ \\
\hline $\begin{array}{l}\text { COMESA } \\
\text { membership }\end{array}$ & $\begin{array}{l}\text { Indicator variable equal to } 1 \text { if both countries in the trading pair are } \\
\text { members of COMESA and } 0 \text { otherwise }\end{array}$ \\
\hline WTO membership & $\begin{array}{l}\text { Indicator variable equal to } 1 \text { if both countries in the trading pair are } \\
\text { members of WTO and } 0 \text { otherwise }\end{array}$ \\
\hline
\end{tabular}

The variables indicating the existence of a trade agreement between a country-pair capture tariff and non-tariff policy measures aimed at lowering bilateral trade costs. The trade agreements considered in the analysis are membership in the EAC, the COMESA, and the WTO. The sample of countries for this study consists of 260 unique country-pairs. The membership of these pairs in the three trade blocs is as follows: Burundi, Kenya, Tanzania, and Uganda joined the WTO in 1995 and Rwanda in 1996. Burundi, Kenya, Rwanda, and Uganda joined COMESA in $1981^{6}$ while Tanzania was a member from 1981 to 2000. Kenya, Tanzania, and Uganda revived the EAC in 2000, with Burundi and Rwanda joining in 2007.

${ }^{6}$ The Treaty establishing COMESA was signed in 1993, replacing the Treaty for the Establishment of the Preferential Trade Area for Eastern and Southern African States, which had been signed in 1981. 
Among the non-EAC trade partners included in the sample, 67 out of 87 joined the WTO in 1995 while 18 joined between 1996 and 2012. Five trade partners (Ethiopia, Madagascar, Malawi, Mauritius, Zambia) joined COMESA in 1981 and one (Egypt) in 1999.

The set of fixed effects included in Equation (17) control for omitted variables that determine total bilateral trade costs and which may also be correlated with the explanatory variables included in the equation. These omitted variables would therefore bias the estimated coefficients on the trade cost proxy variables of interest. The exporter-year and importer-year fixed effects control for time-varying country-specific economic characteristics and policy changes that affect domestic trade costs over time. Most notable among these is the quality of regulatory institutions which determine the ease of doing business domestically. The quality of regulatory institutions would also determine the effectiveness of trade policy measures in enhancing cross-border trade flows (Francois and Manchin 2013, Iwanow and Kirkpatrick 2009, Esfahania and Ram'irez 2003). The exporter-year and importer-year fixed effects also control for changes in multilateral resistance (Mayer and Thoenig 2016), but controlling for multilateral resistance is not necessary since these have been netted out of the total bilateral trade costs estimates (Novy 2013). The industry-year fixed effects control for time-varying differences in production and transportation technologies. These affect the cost of producing goods depending on reliance on imported intermediates and the cost thereof (Milner and McGowan 2013), as well as the cost of transporting goods depending on their weight and/or perishability (Chen and Novy 2011).

The analysis in this section also considers total bilateral trade costs at a more aggregated level of production (that is, total manufacturing). For each country-pair and year in the sample, I derive total bilateral trade costs from production and export data that has been summed up across the 16 industries and use 8 as the elasticity of substitution. ${ }^{7}$ In doing so, I try to show the benefit of disaggregating the data.

Equation (17) is estimated using OLS regression and the results are reported in Table 4. Columns (1) and (2) show results relating to total bilateral trade costs derived from data that is aggregated across the 16 industries, for each country-pair and year in the sample. The number of observations subsequently falls to 2,480 . The average of the total bilateral trade costs estimates inferred from the aggregated data is 4.9 compared with 8.0 when disaggregated data is used (see the second to last row of Table 4). The trade cost estimates from the disaggregated data are larger reflecting the distribution of the elasticity of substitution parameters across industries; about half of the industry parameters are below the average of 7 as shown in Table 1. By the definition of equation (3), the lower the elasticity of substitution parameter, the higher will be the total bilateral trade costs estimate. 


\section{Table 4. Determinants of total bilateral trade costs}

\begin{tabular}{|c|c|c|c|c|c|}
\hline \multirow{3}{*}{$\begin{array}{l}\text { Dependent } \\
\text { variable }\end{array}$} & \multicolumn{5}{|c|}{ In(Total bilateral trade costs) } \\
\hline & \multicolumn{2}{|c|}{ Based on sector-level data } & \multicolumn{3}{|c|}{ Based on industry-level data } \\
\hline & (1) & (2) & (3) & (4) & (5) \\
\hline $\begin{array}{l}\text { In(Bilateral } \\
\text { distance) }\end{array}$ & $\begin{array}{l}0.103 * * \\
(0.042)\end{array}$ & $\begin{array}{c}0.462 * * * \\
(0.126)\end{array}$ & $\begin{array}{c}0.229 * * * \\
(0.058)\end{array}$ & $\begin{array}{c}0.300 * * * \\
(0.050)\end{array}$ & $\begin{array}{c}0.356^{* * *} \\
(0.090)\end{array}$ \\
\hline Common border & $\begin{array}{l}-0.163 \\
(0.099) \\
\end{array}$ & $\begin{array}{l}-0.100 \\
(0.115)\end{array}$ & $\begin{array}{l}-0.033 \\
(0.114)\end{array}$ & $\begin{array}{l}-0.155 \\
(0.103) \\
-\end{array}$ & $\begin{array}{l}-0.302 * * * \\
(0.071)\end{array}$ \\
\hline $\begin{array}{l}\text { Common language } \\
\text { (off.) }\end{array}$ & $\begin{array}{l}-0.068 * \\
(0.041)\end{array}$ & $\begin{array}{l}-0.088 \\
(0.085)\end{array}$ & $\begin{array}{l}-0.124 * \\
(0.072)\end{array}$ & $\begin{array}{c}-0.137 * * \\
(0.065)\end{array}$ & $\begin{array}{c}-0.200 * * \\
(0.085)\end{array}$ \\
\hline Common colonizer & $-0.089^{*}$ & $\begin{array}{c}0.121 \\
(0.098)\end{array}$ & $\begin{array}{c}-0.196 * * \\
(0.084)\end{array}$ & $\begin{array}{l}-0.052 \\
(0.062)\end{array}$ & $\begin{array}{c}0.092 \\
(0.120)\end{array}$ \\
\hline Landlocked & $\begin{array}{l}0.230 * \\
(0.130)\end{array}$ & $\begin{array}{c}0.105 \\
(0.120)\end{array}$ & $\begin{array}{l}-0.099 \\
(0.138)\end{array}$ & $\begin{array}{l}0.227 * * \\
(0.096)\end{array}$ & -0.053 \\
\hline EAC membership & $\begin{array}{l}-0.120^{*} \\
(0.065)\end{array}$ & $\begin{array}{c}0.116 \\
(0.128) \\
\end{array}$ & $\begin{array}{c}-0.235^{* * *} \\
(0.064)\end{array}$ & $\begin{array}{c}-0.205^{* * *} \\
(0.072)\end{array}$ & $\begin{array}{l}-0.291 * * \\
(0.136)\end{array}$ \\
\hline $\begin{array}{l}\text { COMESA } \\
\text { membership } \\
\end{array}$ & $\begin{array}{c}-0.078 * * \\
(0.039)\end{array}$ & $\begin{array}{c}-0.002 \\
(0.087)\end{array}$ & $\begin{array}{l}-0.105^{*} \\
(0.057)\end{array}$ & $\begin{array}{l}-0.018 \\
(0.050)\end{array}$ & $\begin{array}{l}-0.061 \\
(0.050)\end{array}$ \\
\hline WTO membership & $\begin{array}{l}-0.013 \\
(0.037)\end{array}$ & & $\begin{array}{l}-0.025 \\
(0.068)\end{array}$ & $\begin{array}{c}-0.392 * * * \\
(0.104)\end{array}$ & \\
\hline $\begin{array}{l}\text { Exporter-year } \\
\text { fixed effects }\end{array}$ & - & Yes & - & - & Yes \\
\hline $\begin{array}{l}\text { Importer-year } \\
\text { fixed effects }\end{array}$ & - & Yes & - & - & Yes \\
\hline $\begin{array}{l}\text { Industry-year } \\
\text { fixed effects }\end{array}$ & - & - & - & Yes & Yes \\
\hline Observations & 2,480 & 2,480 & 11,095 & 11,095 & 11,095 \\
\hline $\begin{array}{l}\text { Adjusted } \\
R \text {-squared }\end{array}$ & 0.21 & 0.62 & 0.05 & 0.87 & 0.89 \\
\hline $\begin{array}{l}\text { Total bil. trade } \\
\text { costs, mean }\end{array}$ & 4.9 & 4.9 & 8.0 & 8.0 & 8.0 \\
\hline $\begin{array}{l}\text { Bilateral distance, } \\
\text { mean }\end{array}$ & 5,377 & 5,377 & 5,470 & 5,470 & 5,470 \\
\hline
\end{tabular}

(Note) Table 4 shows OLS estimates of Equation (17). The dependent variable for columns (1) and (2) is the natural logarithm of total bilateral trade costs derived from production and trade data that is aggregated across industries. The dependent variable for columns (3) to (5) is the natural logarithm of total bilateral trade costs derived from industry-level production and trade data. Bilateral distance is measured in kilometres. The constant term is not shown in all cases. The standard errors in parentheses are clustered at the country-pair level. Significance levels: $* p<0.10, * * p<0.05, * * *$ $p<0.01$. 
The results in the first column of Table 4 exclude the set of fixed effects. These results indicate that the total bilateral trade costs estimates have the expected relationship with the standard proxies for trade costs. Total bilateral trade costs are higher for country-pairs that are geographically farther apart and for country-pairs that are landlocked, but they are lower for country-pairs that share a common official language, were colonized by the same third country, and are parties to a trade agreement. For the case of aggregated data, I am not able to control for industry-specific effects. The results in column (2) include only exporter-year and importer-year fixed effects, which control for changes in domestic trade costs in the exporter and importer. These fixed effects sweep away the explanatory power of the EAC and COMESA membership variables. The coefficient on EAC membership variable also takes on an unexpected sign. The results in column (2) suggest that EAC total bilateral trade costs are determined by domestic trade costs and the geographical location of trade partners, with no role for the regional trade agreements.

Columns (3) to (5) of Table 4 show total bilateral trade costs results that are derived from industry-level data. Without adding any fixed effects (column 3) and comparing with the results in column (1), the disaggregated data yields larger coefficients (when significant). This means that aggregation bias would be in the downward direction, due to the smaller variance in the aggregated data. I am now also able to control for industry-specific effects. Most of the variation in the total bilateral trade costs estimates occurs at the industry level as indicated by the increase in the $R^{2}$ upon including industry fixed effects (column 4). After averaging out industry-specific characteristics also, membership in the WTO becomes a significant determinant of EAC total bilateral trade costs.

Unlike in the case of the sector-level data, the EAC membership variable retains its explanatory power after inclusion of exporter-year and importer-year fixed effects (column 5 ), as does the presence of a common border and language between a trading pair. The results in column (5) of Table 4 indicate that the average bilateral distance adds $38 \%{ }^{7}$ to total bilateral trade costs. The coefficient on the EAC membership variable indicates that intraEAC total bilateral trade costs are lower than extra-EAC total bilateral trade costs by about $25 \%\left(\left(e^{-0.291}-1\right) \times 100\right)$. This means that the EAC trade agreement almost has the equivalent effect as the average bilateral distance on total bilateral trade costs, but in the opposite direction.

The coefficient on bilateral distance reported in column (5) of Table 4 is in the range of estimates reported in literature. The estimated coefficient on bilateral distance is 0.471 in Chen and Novy (2011) based on industry-level data, and 0.313 in Novy (2013) and 0.355 in Arvis et al. (2016) both based on sector-level data for advanced and developing countries, respectively. The estimated coefficients on the other indicator variables are however comparably lower in the literature; the estimated coefficient on the common border variable is -0.077 in Chen and Novy (2011), -0.154 in Novy (2013) and -0.214 in Arvis et al. (2016). The estimated coefficient on the common language variable is -0.149 in Chen and Novy (2011), -0.027 in Novy (2013), and -0.108 in Arvis et al. (2016). The estimated coefficient

\footnotetext{
${ }^{7}$ This is calculated as $\ln (5,470) \times 0.356 / 8.0$, where 5,470 is the average bilateral distance (in kilometres) between two countries in the sample, and 8.0 is the average total bilateral trade costs between two countries in the sample (see Engel and Rogers 1996).
} 
on the indicator variable for the presence of a trade agreement is -0.068 in Novy (2013) and -0.171 in Arvis et al. (2016). The estimates from the present study thus give a larger role to trade policy measures in determining total bilateral trade costs.

I now turn to the heterogeneity of effects across industries. The analysis in Section 5 showed that total bilateral trade costs correlate positively with the weight-to-value ratio of traded goods and import tariff rates faced by industries. I do not in this paper estimate the impact of these factors on total bilateral trade costs. Regressing trade costs on weightto-value ratio and import tariff rates would give coefficients that reflect the information already given by Figure 6. It would be more informative to determine how industries, given their characteristic differences, respond to the various determinants of trade costs and more importantly to EAC membership. Therefore, I instead group industries by type, according to the amount of technology (measured by R\&D expenditure) used in the production of goods. This categorization also distinguishes the industry groups according to the weight-to-value ratio of traded goods and import tariff rates. The effect of EAC membership on each group is then estimated using Equation (17). The estimated coefficients will indicate how different types of industries respond to the trade cost proxy variables.

The 16 industries are categorized into two groups as follows: ${ }^{8}$ low-technology products (food and beverages; tobacco products; textiles; apparel, fur; leather, leather products, and footwear; wood products (excl. furniture); paper and paper products; basic metals) and medium- to high-technology (printing and publishing; coke, refined petroleum products, nuclear fuel; chemicals and chemical products; rubber and plastics products; non-metallic mineral products; machinery and equipment; motor vehicles, trailers, semi-trailers; furniture; manufacturing n.e.c.). Industries with medium- to high-technology products have a median weight-to-value ratio of 0.4 , and industries with low-technology products have a median weight-to-value ratio of 1.2. Medium- to high-technology products face a median import tariff rate of 14.4 while low-technology products face a median tariff rate of 23.4.

Equation (17) is estimated using OLS regression separately for the two industry groups and the results are reported in Table 5. Columns (1) and (2) show results for industries classified as being medium to high, and low in technology, respectively. In terms of cultural and political ties, the coefficients indicate that a country-pair that shares a common official language has lower trade costs by $20 \%\left(\left(e^{-0.222}-1\right) \times 100\right)$ for low-technology industries as compared with country-pairs that do not share a common official language. The coefficient on the common colonizer variable is not statistically significant for low-technology industries and is wrongly signed for medium- to high-technology industries indicating that a common colonial history does not mitigate EAC trade costs, all other factors considered. Whether country-pairs are landlocked also does not seem to add to EAC trade costs. This result is obtained only after inclusion of exporter-year and importer-year fixed effects.

Total bilateral trade costs are lower by $54 \%\left(\left(e^{-0.787}-1\right) \times 100\right)$ for medium- to hightechnology industries when the pair of countries are members of the EAC, whereas total bilateral trade costs among members of COMESA are lower by $19 \%$ for low-technology

${ }^{8}$ This grouping follows the classification of products used by the Organization for Economic Co-operation and Development (OECD). The classification is explained in Hatzichronoglou (1997). 
industries. These effects compare with the effect of distance on total bilateral trade costs of $23 \%(\ln (5,454) \times 0.257 / 9.6)$ for medium- to high-technology industries and $42 \%(\ln (5,488)$ $\times 0.314 / 6.5$ ) for low-technology industries. A common border between a country-pair has a comparable smaller negative impact on the trade costs of low-technology industries. It is noteworthy that low-technology manufactured goods are more predominantly traded with non-EAC partners. For these industries, therefore, transport-related trade costs and a trade agreement with wider membership are more important in determining cross-border trade costs.

The results reported in this section show that the total bilateral trade costs estimates are reasonably related to known proxies of trade costs. The results also show the EAC trade agreement to be an important determinant of the trade costs. The closing analysis suggests that the EAC trade agreement is more relevant in influencing the total bilateral trade costs of some industries more than others. This motivates further inquiry into the effect of EAC trade policies on total bilateral trade costs and the distribution thereof across the various industries in the manufacturing sector.

Table 5. Determinants of total bilateral trade costs

(by industry group)

\begin{tabular}{|c|c|c|}
\hline \multirow{3}{*}{ Dependent variable } & \multicolumn{2}{|c|}{ In(Total bilateral trade costs) } \\
\hline & $\begin{array}{c}\text { Medium- to high-tech } \\
\text { industries }\end{array}$ & Low-tech industries \\
\hline & (1) & (2) \\
\hline In(Bilateral distance) & $\begin{array}{l}0.257 * * \\
(0.124)\end{array}$ & $\begin{array}{l}0.314 * * * \\
(0.099)\end{array}$ \\
\hline Common border & $-0.490 * * *$ & $-0.216^{* *}$ \\
\hline Common language (official) & & $-0.222 * * *$ \\
\hline Common colonizer & $\begin{array}{l}0.274 * \\
(0.143)\end{array}$ & \\
\hline Landlocked & $\begin{array}{c}-0.014 \\
(0.100)\end{array}$ & $(0.104)$ \\
\hline EAC membership & $-0.787 * * *$ & $\begin{array}{l}-0.001 \\
(0.157)\end{array}$ \\
\hline COMESA membership & $\begin{array}{r}0.040 \\
(0.057) \\
\end{array}$ & $\begin{array}{c}-0.209^{* * *} \\
(0.074) \\
\end{array}$ \\
\hline Exporter-year fixed effects & Yes & Yes \\
\hline Importer-year fixed effects & Yes & Yes \\
\hline Industry-year fixed effects & Yes & Yes \\
\hline Observations & 5,922 & 5,173 \\
\hline Adjusted R-squared & 0.91 & 0.80 \\
\hline Total bilateral trade costs, mean & 9.6 & 6.5 \\
\hline Bilateral distance, mean & 5,454 & 5,488 \\
\hline Weight-to-value ratio, median & 0.4 & 1.2 \\
\hline Import tariff rate, median & 14.4 & 23.4 \\
\hline
\end{tabular}


(Note) Table 5 shows OLS estimates of Equation (17). The dependent variable is the natural logarithm of total bilateral trade costs derived from industry-level data. The medium- to high-technology industries of column (1) are printing and publishing; coke, refined petroleum products, nuclear fuel; chemicals and chemical products; rubber and plastics products; non-metallic mineral products; machinery and equipment; motor vehicles, trailers, semi-trailers; furniture; manufacturing n.e.c. The low-technology industries of column (2) are food and beverages; tobacco products; textiles; wearing apparel, fur; leather, leather products and footwear; wood products (excl. furniture); paper and paper products; basic metals. Weight-to-value ratio is calculated from import data averaged across country-pairs. The import tariff rate is the effectively applied rate of the exporter. The constant term is not shown in all cases. The standard errors in parentheses are clustered at the country-pair level. Significance levels: * $p<0.10, * * p<0.05, * * * p<0.01$.

\section{Robustness Checks}

In this section, the baseline results reported in Table 4, column (5) are assessed for endogeneity biases coming from mismeasurement of the total bilateral trade costs. Mismeasurement errors may arise from estimating a common elasticity of substitution parameter for the EAC market as opposed to each EAC country.

To determine the effect of the choice of elasticity of substitution parameter on the total bilateral trade costs estimates, two other sets of total bilateral trade costs estimates are calculated; one where the elasticity of substitution parameter varies by EAC country and by industry, and another where the elasticity of substitution parameter is set at 8 for all EAC countries and all industries. Figure 7 plots the baseline and the other two sets of total bilateral trade costs estimates for each industry, averaged across country-pairs and time.

In Figure 7, the grey dots represent the average total bilateral trade costs for each industry, which are derived assuming an elasticity of substitution parameter of 8 for all industries and countries. These estimates average to 3.8 and do not exceed 5. The black dots represent the average of the baseline total bilateral trade costs for each industry, which are derived assuming that the elasticity of substitution parameter varies across industries but not across EAC countries. The highest of these estimates is 93 for ISIC Code 23 (fuel products) and 542 for ISIC Code 26 (non-metallic mineral products). The white dots represent trade costs estimates calculated using an elasticity of substitution parameter that varies by industry and EAC country. The average of these estimates is well over 1000 (most observations are off the chart). Therefore, the more the elasticity of substitution parameter varies by industry and country, the more likely larger total bilateral trade costs estimates are obtained. Restricting the variability of the elasticity of substitution parameter therefore puts an upper limit on the total bilateral trade costs estimates. 


\section{Figure 7. Size of total bilateral trade costs estimates given different elasticity of substitution parameters}

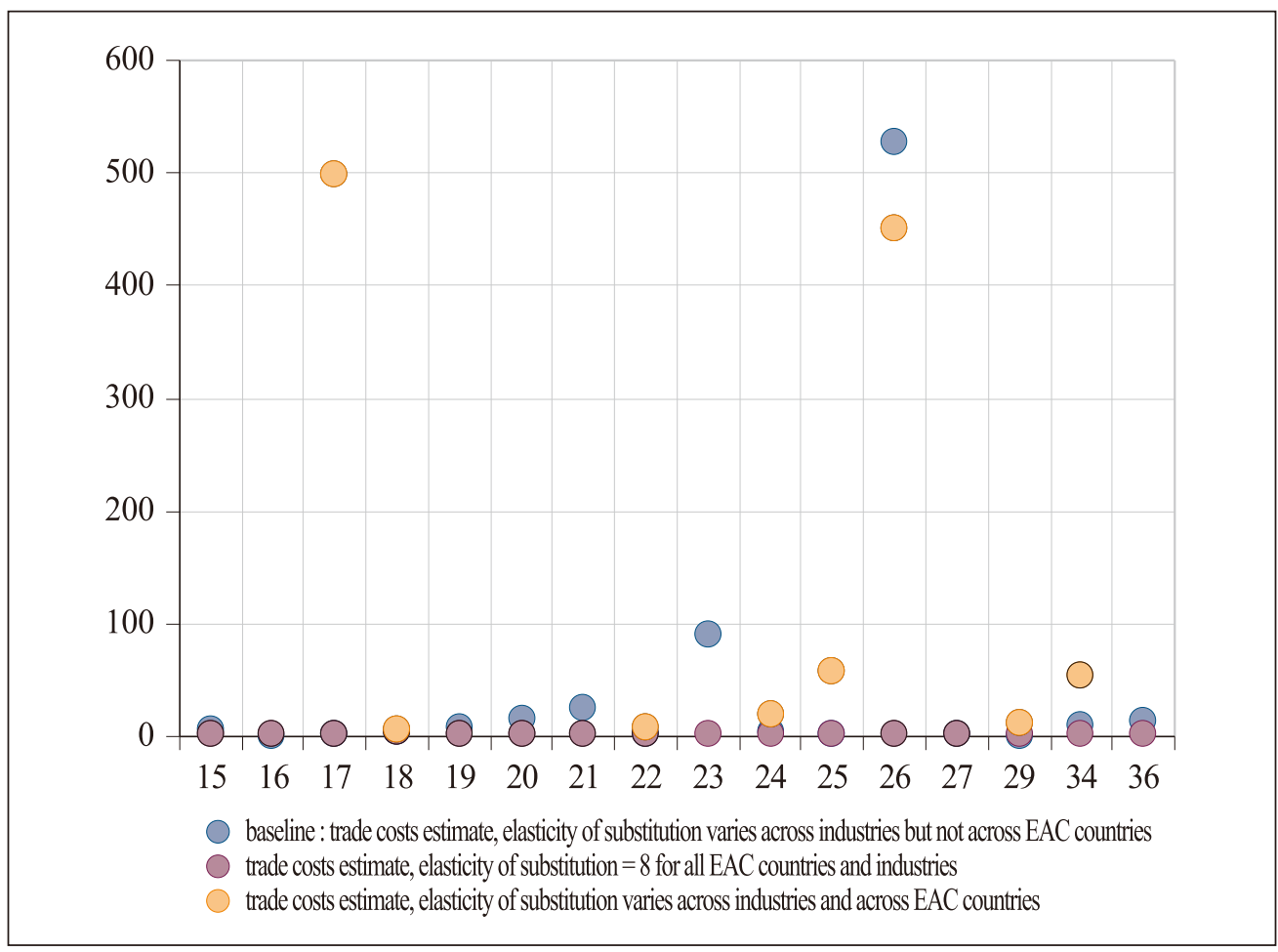

Further, the variance in the trade costs estimates also depends on the variability of elasticity of substitution parameter as shown in Figure 8. The more variable is the elasticity of substitution parameter across industries and EAC countries, the higher is the variance in the trade costs estimates.

The implication is that the size of OLS estimates from regressions of total bilateral trade costs will increase with variability of the elasticity of substitution parameter. Or, the more the data is disaggregated, the larger will be the estimated coefficients. Since the level and variance in trade costs estimates are sensitive to the elasticity of substitution estimate, I think it better to derive the elasticities from the same data (and disaggregation level) from which the total bilateral trade costs are derived.

Further robustness checks on the baseline results are presented in Appendix 6. These relate to the use of mirror trade data for Kenya instead of data reported by Kenya, which has gaps. The tests show that the baseline results are robust to the use of mirror trade data for Kenya. Appendix 6 also includes a comparison of the total bilateral trade costs estimates and the residuals from a general gravity model as a way of gauging the validity of the estimates. In this regard, the total bilateral trade costs estimates are found to be reliable. 


\section{Figure 8. Variance in total bilateral trade costs estimates given different elasticity of substitution parameters}

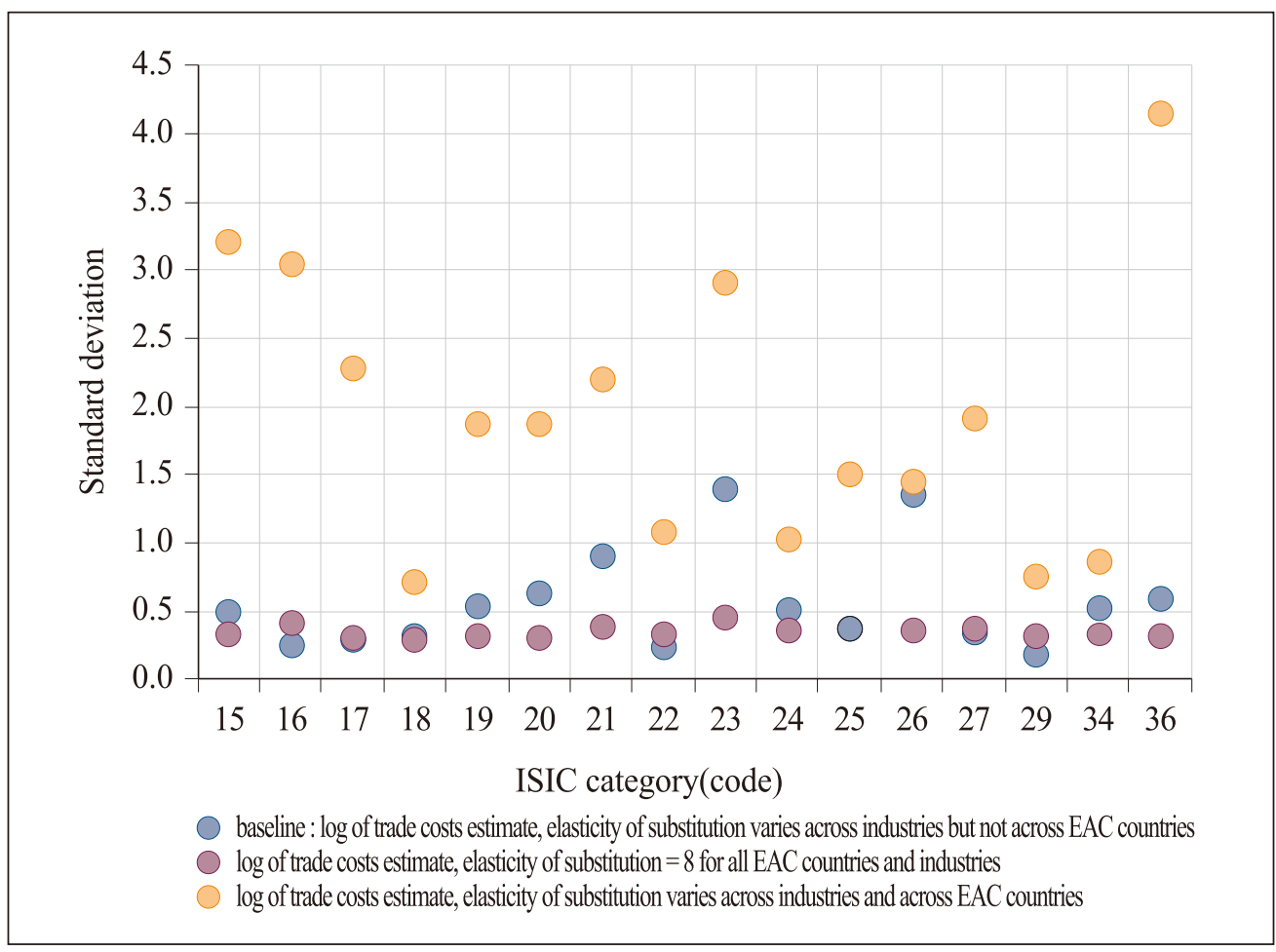

\section{Conclusions}

The objective of this study is to estimate total bilateral trade costs for manufacturing industries of the EAC. Total bilateral trade cost is a single measure that captures all the costs of engaging in cross-border trade relative to the cost of engaging in domestic trade. The measure is estimated from production and bilateral trade data using the inverse-gravity method of Chen and Novy (2011). The total bilateral trade costs estimates may serve as the basis for evaluating trade policy measures associated with EAC membership. The estimates are useful for policy evaluation exercises because they capture a wide range of trade-related costs and thus allow for comprehensive analysis of various trade policy measures.

This study uses data on production and exports of manufactured goods in 16 industries for five members of the EAC and 87 trade partners over the period 1990 2012. The largest among the industries in terms of the value of output and cross-border trade are those manufacturing food and beverages, chemicals and chemical products, and non-metallic mineral products. A wider range of goods is produced and traded by Kenya and Tanzania as compared with the other EAC countries. The elasticities of substitution among the goods, which are needed to calculate the total bilateral trade costs, are estimated using the method in 
Feenstra (1994). The elasticity of substitution parameters for the dominant industries average to 7 compared with the range of elasticity of substitution parameters for all industries of 3 to 14 . The total bilateral trade costs estimates generated using these parameters average to 8 (excluding outliers) and range from 1 to 14,826. This means that for EAC countries, crossborder trade costs are on average 8 times higher than domestic trade costs. Robustness checks confirm the total bilateral trade costs estimates to be reliable albeit sensitive to the elasticity of substitution parameter. It is therefore appropriate that both the total bilateral trade costs and elasticity of substitution parameters are estimated at the same level of disaggregation.

Simple comparative analysis shows that EAC total bilateral trade costs are lower with respect to coastal trade partners located closer to the region. The analysis also shows that intra-EAC total bilateral trade costs trended downwards after 1999, coinciding with the coming into effect of the EAC Treaty. In terms of the distribution of estimates across industries, the comparative analysis shows that industries with higher total bilateral trade costs also tend to have higher product weight-to-value ratios and face higher import tariff rates. These findings indicate geographical location and trade policy measures to be determinants of the total bilateral trade costs.

More formally, results from OLS regressions indicate that total bilateral trade costs of EAC countries increase with geographical distance and decrease with trade agreements. The EAC trade agreement is found to be particularly important in determining the total bilateral trade costs, suggesting that the costs are amenable to policy intervention. Further regression results show that the influence of the EAC trade agreement on trade costs varies across industries.

The findings of this paper motivate further study of the relationship between the total bilateral trade costs estimates and specific policy measures implemented under the EAC Treaty. Of interest is the effect on total bilateral trade costs of the removal of import tariffs and the upgrading of transportation infrastructure. This is because the removal of import tariffs is the longest standing, having been completed in 2009, while the ongoing upgrading of transportation infrastructure is the most expensive venture yet.

\section{Policy Implications}

This study finds that the EAC trade agreement has achieved some level of integration among member countries through lowering cross-border trade barriers. However, the uneven distribution of the cost-cutting effects of the agreement implies that within the manufacturing sector there may be a limit to the gains from EAC membership. This finding points to the need for a strategy to rope in industries that may gain less from co-operation among only EAC countries. The need for such a strategy lends some importance to initiatives such as the COMESA-EAC-SADC Tripartite Free Trade Area Agreement, which seeks to enhance trade among members of the EAC, COMESA, and Southern African Development Community (SADC) trading blocs. The Tripartite agreement would be particularly useful for the group of industries whose international trade costs are mitigated more by a trade agreement with wider 
membership.

Received 9 November 2018, Revised 7 January 2019, Accepted 17 January 2019 


\section{References}

James E. Anderson and Eric van Wincoop. "Gravity with Gravitas: A Solution to the Border Puzzle”. American Economic Review, 93(1):170-192, 2003.

James E. Anderson and Eric van Wincoop. "Trade Costs". Journal of Economic Literature, 42(3) (2004): 691-751.

Jean-Franc, ois Arvis, Yann Duval, Ben Shepherd, Chorthip Utoktham, and Anasuya Raj. "Trade Costs in the Developing World: 1996 - 2010". World Trade Review, 15(3):451-474, 2016.

Scott L. Baier and Jeffrey H. Bergstrand. "Estimating the Effects of Free Trade Agreements on International Trade Flows Using Matching Econometrics". Journal of International Economics, 77(1) (2009): 63-76.

Jeffrey H. Bergstrand, Mario Larch, and Yoto V. Yotov. "Economic Integration Agreements, Border Effects, and Distance Elasticities in the Gravity Equation". European Economic Review, 78:307-327, 2015.

Christian Broda and David E. Weinstein. "Globalisation and the Gains from Variety". Quarterly Journal of Economics, 121(2) (2006): 541-585.

Natalie Chen. "Intra-National Versus International Trade in the European Union: Why Do National Borders Matter?”. Journal of International Economics, 63(1) (2004): 93-118.

Natalie Chen and Dennis Novy. "Gravity, Trade Integration, and Heterogeneity Across Industries”. Journal of International Economics, 85(2) (2011): 206-221.

Peter H. Egger and Nigai Sergey. "Structural Gravity with Dummies Only: Constrained ANOVAType Estimation of Gravity Models". Journal of International Economics, 97(1) (2015): 86-99.

Charles Engel and John H. Rogers. "How Wide Is the Border?". American Economic Review, 86(5):1112-1125, 1996.

Hadi Salehi Esfahania and Mar'1a Teresa Ram'1rez. "Institutions, Infrastructure, and Economic Growth". Journal of Development Economics, 70(2) (2003): 443-477.

Robert C. Feenstra. "New Goods and Index Numbers: U.S. Import Prices". Working Paper 3610, National Bureau of Economic Research, Cambridge, Massachusetts, 1991. 
Robert C. Feenstra. "New Product Varieties and the Measurement of International Prices". American Economic Review, 84(1):157-177, 1994.

Robert C. Feenstra. Advanced International Trade: Theory and Evidence. Princeton University Press, 2004.

Joseph Francois and Miriam Manchin. "Institutions, Infrastructure, and Trade". World Development, 46:165-175, 2013.

Scott French. "The Composition of Trade Flows and the Aggregate Effects of Trade Barriers". Journal of International Economics, 98 (2016): 114-137.

Thomas Hatzichronoglou. "Revision of the High-Technology Sector and Product Classification". Working Paper 2, OECD Directorate for Science, Technology and Industry, Paris, 1997.

Keith Head and Thierry Mayer. "Illusory Border Effects: Distance Mismeasurement Inflates Estimates of Home Bias in Trade". Working Paper 2002-01, Centre d'Etudes Prospectives' et d'Informations Internationales (CEPII), Paris, 2002.

Elhanan Helpman, Marc Melitz, and Yona Rubinstein. "Estimating Trade Flows: Trading Partners and Trading Volumes". Quarterly Journal of Economics, 123(2) (2008): 441-487.

Jean M. Imbs and Isabelle Mejean. "Elasticity Optimism". Discussion Paper DP7177, Centre for Economic Policy Research, 2009.

Tomasz Iwanow and Colin Kirkpatrick. "Trade Facilitation and Manufactured Exports: Is AfricaDifferent?". World Development, 37(6):1039-1050, 2009.

David S. Jacks, Christopher M. Meissner, and Dennis Novy. "Trade Costs in the First Wave of Globalization”. Explorations in Economic History, 47(2):127-141, 2010.

David S. Jacks, Christopher M. Meissner, and Dennis Novy. "Trade Booms, Trade Busts and Trade Costs". Journal of International Economics, 83(2) (2011): 185-201.

Thierry Mayer and Mathias Thoenig. "Regional Trade Agreements and the Pacification of Eastern Africa”. Working paper, International Growth Centre, London, June 2016.

Chris Milner and Danny McGowan. "Trade Costs and Trade Composition". Economic Inquiry, 51(3):1886-1902, 2013.

Dennis Novy. "Gravity Redux: Measuring International Trade Costs with Panel Data". 
Economic Inquiry, 51(1):101-121, 2013.

Andrew K. Rose. “Do We Really Know That the WTO Increases Trade?”. American Economic Review, 94(1):98-114, 2004.

Santos Silva and Silvana Tenreyro. "The Log of Gravity". Review of Economics and Statistics, 88(4):641-658, 2006.

Vincent Vicard. "Determinants of Successful Regional Trade Agreements". Economics Letters, 111(3):188-190, 2011. 


\section{Appendix 1: Composition and trade of manufactured output}

(averages for period 1990 2012)

\begin{tabular}{|c|c|c|c|c|c|}
\hline ISIC code and description & Burundi & Kenya & Rwanda & Tanzania & Uganda \\
\hline \multicolumn{6}{|c|}{ Panel A. Share in total manufactured output (\%) } \\
\hline 15 Food and beverages & 82 & 43 & 71 & 41 & 38 \\
\hline 16 Tobacco products & 1 & 1 & 1 & 6 & 4 \\
\hline 17 Textiles & 3 & 2 & 2 & 6 & 6 \\
\hline 18 Wearing apparel, fur & 0 & 2 & & 1 & \\
\hline 19 Leather, leather products and footwear & 0 & 2 & 2 & 0 & 1 \\
\hline 20 Wood products (excl. furniture) & 1 & 1 & 0 & 1 & \\
\hline 21 Paper and paper products & 0 & 3 & 1 & 2 & 5 \\
\hline 22 Printing and publishing & 1 & 2 & 6 & 3 & 2 \\
\hline 23 Coke, refined petroleum products, nuclear fuel & & 11 & & 1 & \\
\hline 24 Chemicals and chemical products & 5 & 7 & 3 & 9 & 8 \\
\hline 25 Rubber and plastics products & 0 & 3 & 1 & 9 & 3 \\
\hline 26 Non-metallic mineral products & 1 & 5 & 5 & 9 & 7 \\
\hline 27 Basic metals & 2 & 3 & 4 & 2 & 12 \\
\hline 29 Machinery and equipment n.e.c. & & 1 & & 1 & \\
\hline 34 Motor vehicles, trailers, semi-trailers & & 4 & & 1 & \\
\hline 36 Furniture; manufacturing n.e.c. & 0 & 1 & 3 & 1 & 3 \\
\hline \multicolumn{6}{|c|}{ Panel B. Share of manufactured output that was exported outside the EAC (\%) } \\
\hline 15 Food and beverages & 0 & 7 & 1 & 7 & 29 \\
\hline 16 Tobacco products & & 6 & 0 & 0 & 0 \\
\hline 17 Textiles & 7 & 8 & 0 & 12 & 15 \\
\hline 18 Wearing apparel, fur & & 8 & & 3 & \\
\hline 19 Leather, leather products and footwear & 7 & 14 & 9 & 19 & 6 \\
\hline 20 Wood products (excl. furniture) & 0 & 6 & 4 & 12 & \\
\hline 21 Paper and paper products & 0 & 1 & 1 & 2 & 0 \\
\hline 22 Printing and publishing & 0 & 5 & 0 & 1 & 4 \\
\hline 23 Coke, refined petroleum products, nuclear fuel & & 3 & & 2 & \\
\hline 24 Chemicals and chemical products & 1 & 9 & 3 & 5 & 1 \\
\hline 25 Rubber and plastics products & & 2 & 0 & 1 & 0 \\
\hline 26 Non-metallic mineral products & 0 & 2 & 0 & 3 & 0 \\
\hline 27 Basic metals & 0 & 3 & 5 & 8 & 7 \\
\hline 29 Machinery and equipment n.e.c. & & 3 & & 35 & \\
\hline 34 Motor vehicles, trailers, semi-trailers & & 0 & & 18 & \\
\hline 36 Furniture; manufacturing n.e.c. & & 3 & 0 & 3 & 1 \\
\hline \multicolumn{6}{|c|}{ Panel C. Share of manufactured output that was exported to the EAC (\%) } \\
\hline 15 Food and beverages & 0 & 1 & 7 & 2 & 22 \\
\hline 16 Tobacco products & & 6 & 1 & 0 & 1 \\
\hline 17 Textiles & 1 & 4 & 2 & 13 & 5 \\
\hline 18 Wearing apparel, fur & & 0 & & 0 & \\
\hline 19 Leather, leather products and footwear & 4 & 0 & 5 & 1 & 2 \\
\hline 20 Wood products (excl. furniture) & 0 & 3 & 0 & 8 & \\
\hline 21 Paper and paper products & 0 & 7 & 1 & 3 & 2 \\
\hline 22 Printing and publishing & 0 & 5 & 0 & 0 & 4 \\
\hline 23 Coke, refined petroleum products, nuclear fuel & & 7 & & 21 & \\
\hline 24 Chemicals and chemical products & 2 & 18 & 3 & 2 & 16 \\
\hline 25 Rubber and plastics products & & 10 & 2 & 2 & 3 \\
\hline 26 Non-metallic mineral products & 0 & 9 & 4 & 1 & 12 \\
\hline 27 Basic metals & 0 & 17 & 8 & 0 & 23 \\
\hline 29 Machinery and equipment n.e.c. & & 4 & & 1 & \\
\hline 34 Motor vehicles, trailers, semi-trailers & & 0 & & 2 & \\
\hline 36 Furniture; manufacturing n.e.c. & & 3 & 0 & 2 & 1 \\
\hline
\end{tabular}

(Note) The difference between total production and exports outside the EAC plus exports to the EAC is assumed to be domestic consumption.

(Source) Author's calculations based on data from INDSTAT2 and COMTRADE online databases. 


\section{Appendix 2: List of countries and territories included in the study}

(EAC countries in bold)

\begin{tabular}{|c|c|c|c|}
\hline Albania & Estonia & Latvia & Russian Federation \\
\hline Algeria & Ethiopia & Lithuania & Rwanda \\
\hline Australia & Fiji & Luxembourg & Saudi Arabia \\
\hline Austria & Finland & Macedonia, FYR & Senegal \\
\hline Azerbaijan & France & Madagascar & Singapore \\
\hline Bangladesh & Georgia & Malawi & Slovak Republic \\
\hline Belgium & Germany & Malaysia & Slovenia \\
\hline Botswana & Greece & Malta & South Africa \\
\hline Brazil & Hong Kong, China & Mauritius & Spain \\
\hline Bulgaria & Hungary & Mexico & Sri Lanka \\
\hline Burundi & Iceland & Morocco & Sweden \\
\hline Cameroon & India & Namibia & Switzerland \\
\hline Canada & Indonesia & Netherlands & Tanzania \\
\hline Chile & Iran & New Zealand & Thailand \\
\hline China & Ireland & Norway & Tunisia \\
\hline Colombia & Israel & Oman & Turkey \\
\hline Congo, Rep. & Italy & Pakistan & Uganda \\
\hline Costa Rica & Japan & Peru & Ukraine \\
\hline Cyprus & Jordan & Philippines & United Kingdom \\
\hline Czech Republic & Kazakhstan & Poland & United States \\
\hline Denmark & Kenya & Portugal & Vietnam \\
\hline Ecuador & Korea, Rep. & Qatar & Yemen \\
\hline Egypt & Kuwait & Romania & Zambia \\
\hline
\end{tabular}

\section{Appendix 3: List of ISIC categories included in the study}

\begin{tabular}{|c|c|}
\hline ISIC code & Description \\
\hline 15 & Manufacture of food products and beverages \\
\hline 16 & Manufacture of tobacco products \\
\hline 17 & Manufacture of textiles \\
\hline 18 & Manufacture of wearing apparel; dressing and dyeing of fur \\
\hline 19 & Tanning and dressing of leather; manufacture of luggage, handbags, saddlery, harness and footwear \\
\hline 20 & $\begin{array}{l}\text { Manufacture of wood and of products of wood and cork, except furniture; manufacture of articles of straw and } \\
\text { plaiting materials }\end{array}$ \\
\hline 21 & Manufacture of paper and paper products \\
\hline 22 & Publishing, printing and reproduction of recorded media \\
\hline 23 & Manufacture of coke, refined petroleum products and nuclear fuel \\
\hline 24 & Manufacture of chemicals and chemical products \\
\hline 25 & Manufacture of rubber and plastics products \\
\hline 26 & Manufacture of non-metallic mineral products \\
\hline 27 & Manufacture of basic metals \\
\hline 29 & Manufacture of machinery and equipment n.e.c. \\
\hline 34 & Manufacture of motor vehicles, trailers, semi-trailers \\
\hline 36 & Manufacture of furniture; manufacturing n.e.c. \\
\hline
\end{tabular}




\section{Appendix 4: List of dominant suppliers by EAC country and ISIC category}

\begin{tabular}{|c|c|c|c|}
\hline Importer & Dominant supplier & Importer & Dominant supplier \\
\hline \multicolumn{2}{|c|}{15 Food and beverages } & \multicolumn{2}{|c|}{23 Coke, refined petroleum products, nuclear fuel } \\
\hline Burundi & Italy & \multirow{5}{*}{$\begin{array}{l}\text { Burundi } \\
\text { Kenya } \\
\text { Rwanda } \\
\text { Uganda } \\
\text { Tanzania }\end{array}$} & Kenya \\
\hline Kenya & Indonesia & & Singapore \\
\hline Rwanda & Uganda & & Kenya \\
\hline Uganda & Kenya & & India \\
\hline Tanzania & Indonesia & & India \\
\hline \multicolumn{2}{|c|}{16 Tobacco products } & \multicolumn{2}{|c|}{24 Chemicals and chemical products } \\
\hline Burundi & Kenya & Burundi & India \\
\hline Kenya & India & Kenya & India \\
\hline Rwanda & Kenya & Rwanda & India \\
\hline Uganda & Kenya & Uganda & India \\
\hline Tanzania & India & Tanzania & India \\
\hline & 17 Textiles & \multicolumn{2}{|c|}{25 Rubber and plastics products } \\
\hline Burundi & China & Burundi & China \\
\hline Kenya & India & Kenya & India \\
\hline Rwanda & China & Rwanda & Kenya \\
\hline Uganda & China & Uganda & Kenya \\
\hline Tanzania & China & Tanzania & China \\
\hline \multicolumn{2}{|c|}{18 Wearing apparel, fur } & \multicolumn{2}{|c|}{26 Non-metallic mineral products } \\
\hline Burundi & United Arab Emirates & Burundi & Zambia \\
\hline Kenya & India & Kenya & India \\
\hline Rwanda & United Arab Emirates & Rwanda & Uganda \\
\hline Uganda & United Arab Emirates & Uganda & Kenya \\
\hline Tanzania & China & Tanzania & China \\
\hline & eather products and footwear & & 27 Basic metals \\
\hline Burundi & France & Burundi & Kenya \\
\hline Kenya & Thailand & Kenya & India \\
\hline Rwanda & United Arab Emirates & Rwanda & Uganda \\
\hline Uganda & China & Uganda & Kenya \\
\hline Tanzania & China & Tanzania & China \\
\hline & products (excl. furniture) & & ery and equipment n.e.c. \\
\hline Burundi & Kenya & Burundi & France \\
\hline Kenya & India & Kenya & India \\
\hline Rwanda & China & Rwanda & China \\
\hline Uganda & Kenya & Uganda & India \\
\hline Tanzania & China & Tanzania & China \\
\hline & er and paper products & & aicles, trailers, semi-trailers \\
\hline Burundi & United Arab Emirates & Burundi & Japan \\
\hline Kenya & India & Kenya & Japan \\
\hline Rwanda & Kenya & Rwanda & Japan \\
\hline Uganda & Kenya & Uganda & Japan \\
\hline Tanzania & Kenya & Tanzania & Japan \\
\hline & inting and publishing & & ire; manufacturing n.e.c. \\
\hline Burundi & France & Burundi & China \\
\hline Kenya & India & Kenya & India \\
\hline Rwanda & Kenya & Rwanda & China \\
\hline Uganda & United Kingdom & Uganda & China \\
\hline Tanzania & United Kingdom & Tanzania & China \\
\hline
\end{tabular}




\section{Appendix 5: Summary statistics for total bilateral trade costs}

\begin{tabular}{|c|c|c|c|c|c|c|c|}
\hline Exporter & ISIC code & Description & Obs. & Mean & Std. dev. & Min. & Max. \\
\hline Burundi & 15 & Food and beverages & 23 & 11.2 & 6.1 & 4.2 & 27.9 \\
\hline Burundi & 17 & Textiles & 9 & 2.9 & 1.0 & 2.1 & 5.0 \\
\hline Burundi & 19 & Leather, leather products and footwear & 3 & 14.7 & 11.2 & 6.7 & 27.4 \\
\hline Burundi & 20 & Wood products (excl. furniture) & 8 & 20.2 & 7.0 & 5.4 & 27.1 \\
\hline Burundi & 21 & Paper and paper products & 7 & 32.5 & 24.3 & 8.7 & 81.9 \\
\hline Burundi & 22 & Printing and publishing & 16 & 2.9 & 0.6 & 2.0 & 3.9 \\
\hline Burundi & 24 & Chemicals and chemical products & 8 & 4.7 & 2.4 & 1.8 & 8.2 \\
\hline Burundi & 26 & Non-metallic mineral products & 8 & 785.3 & 1083.9 & 20.2 & 3340.9 \\
\hline Burundi & 27 & Basic metals & 2 & 1.9 & 0.2 & 1.8 & 2.1 \\
\hline Kenya & 15 & Food and beverages & 886 & 7.3 & 4.2 & 1.6 & 46.7 \\
\hline Kenya & 16 & Tobacco products & 25 & 1.9 & 0.4 & 1.3 & 2.8 \\
\hline Kenya & 17 & Textiles & 660 & 3.2 & 0.9 & 1.2 & 8.1 \\
\hline Kenya & 18 & Wearing apparel, fur & 313 & 5.7 & 1.9 & 2.0 & 20.0 \\
\hline Kenya & 19 & Leather, leather products and footwear & 301 & 9.8 & 5.6 & 2.4 & 38.7 \\
\hline Kenya & 20 & Wood products (excl. furniture) & 420 & 17.2 & 12.4 & 1.4 & 157.7 \\
\hline Kenya & 21 & Paper and paper products & 351 & 29.2 & 34.8 & 2.2 & 460.8 \\
\hline Kenya & 22 & Printing and publishing & 483 & 2.9 & 0.7 & 1.6 & 6.2 \\
\hline Kenya & 23 & Coke, refined petroleum products, nuclear fuel & 66 & 102.8 & 142.2 & 1.1 & 968.2 \\
\hline Kenya & 24 & Chemicals and chemical products & 690 & 5.2 & 2.6 & 1.2 & 22.1 \\
\hline Kenya & 25 & Rubber and plastics products & 524 & 3.9 & 1.3 & 1.2 & 9.9 \\
\hline Kenya & 26 & Non-metallic mineral products & 627 & 500.5 & 1245.3 & 1.2 & 14825.9 \\
\hline Kenya & 27 & Basic metals & 250 & 3.1 & 1.0 & 1.0 & 7.8 \\
\hline Kenya & 29 & Machinery and equipment n.e.c. & 444 & 2.0 & 0.3 & 1.1 & 4.3 \\
\hline Kenya & 34 & Motor vehicles, trailers, semi-trailers & 291 & 11.4 & 5.7 & 2.1 & 36.2 \\
\hline Kenya & 36 & Furniture; manufacturing n.e.c. & 579 & 14.9 & 9.7 & 2.3 & 102.1 \\
\hline Rwanda & 15 & Food and beverages & 108 & 9.3 & 4.3 & 1.6 & 29.2 \\
\hline Rwanda & 16 & Tobacco products & 1 & 2.8 & . & 2.8 & 2.8 \\
\hline Rwanda & 17 & Textiles & 40 & 3.3 & 1.0 & 1.3 & 5.7 \\
\hline Rwanda & 19 & Leather, leather products and footwear & 6 & 9.4 & 3.7 & 3.8 & 15.3 \\
\hline Rwanda & 20 & Wood products (excl. furniture) & 22 & 18.7 & 8.1 & 3.1 & 35.9 \\
\hline Rwanda & 21 & Paper and paper products & 16 & 15.0 & 16.8 & 2.8 & 54.4 \\
\hline Rwanda & 22 & Printing and publishing & 66 & 2.9 & 0.5 & 1.7 & 4.7 \\
\hline Rwanda & 24 & Chemicals and chemical products & 35 & 4.7 & 2.2 & 1.3 & 10.1 \\
\hline Rwanda & 25 & Rubber and plastics products & 19 & 3.4 & 1.3 & 1.4 & 5.4 \\
\hline Rwanda & 26 & Non-metallic mineral products & 19 & 438.1 & 417.3 & 3.4 & 1375.0 \\
\hline Rwanda & 27 & Basic metals & 15 & 3.3 & 1.5 & 1.3 & 7.0 \\
\hline Rwanda & 36 & Furniture; manufacturing n.e.c. & 24 & 15.6 & 9.3 & 3.3 & 40.1 \\
\hline
\end{tabular}

(Source) Author's calculations based on data from INDSTAT2 and COMTRADE online databases. 
(continued)

\begin{tabular}{|c|c|c|c|c|c|c|c|}
\hline Exporter & ISIC code & Description & Obs. & Mean & Std. dev. & Min. & Max. \\
\hline Tanzania & 15 & Food and beverages & 528 & 7.6 & 4.5 & 2.2 & 46.7 \\
\hline Tanzania & 16 & Tobacco products & 12 & 2.5 & 0.5 & 1.7 & 3.7 \\
\hline Tanzania & 17 & Textiles & 362 & 3.1 & 0.8 & 1.2 & 5.6 \\
\hline Tanzania & 18 & Wearing apparel, fur & 19 & 5.0 & 1.9 & 2.0 & 8.1 \\
\hline Tanzania & 19 & Leather, leather products and footwear & 54 & 8.6 & 4.5 & 3.6 & 24.6 \\
\hline Tanzania & 20 & Wood products (excl. furniture) & 240 & 18.1 & 12.7 & 3.3 & 91.5 \\
\hline Tanzania & 21 & Paper and paper products & 69 & 20.8 & 13.2 & 2.9 & 54.4 \\
\hline Tanzania & 22 & Printing and publishing & 221 & 3.0 & 0.5 & 2.0 & 4.7 \\
\hline Tanzania & 23 & Coke, refined petroleum products, nuclear fuel & 17 & 57.3 & 72.1 & 2.2 & 268.7 \\
\hline Tanzania & 24 & Chemicals and chemical products & 332 & 6.3 & 3.2 & 1.7 & 24.4 \\
\hline Tanzania & 25 & Rubber and plastics products & 216 & 4.0 & 1.4 & 1.6 & 8.7 \\
\hline Tanzania & 26 & Non-metallic mineral products & 250 & 670.3 & 1217.2 & 7.4 & 9249.8 \\
\hline Tanzania & 27 & Basic metals & 12 & 3.1 & 0.7 & 1.8 & 4.5 \\
\hline Tanzania & 29 & Machinery and equipment n.e.c. & 80 & 1.7 & 0.3 & 1.1 & 2.5 \\
\hline Tanzania & 34 & Motor vehicles, trailers, semi-trailers & 42 & 6.6 & 3.5 & 2.6 & 17.7 \\
\hline Tanzania & 36 & Furniture; manufacturing n.e.c. & 276 & 16.2 & 10.9 & 3.3 & 95.8 \\
\hline Uganda & 15 & Food and beverages & 208 & 6.3 & 2.9 & 1.7 & 21.2 \\
\hline Uganda & 16 & Tobacco products & 3 & 2.2 & 0.5 & 1.8 & 2.7 \\
\hline Uganda & 17 & Textiles & 80 & 3.2 & 1.1 & 1.4 & 8.7 \\
\hline Uganda & 19 & Leather, leather products and footwear & 20 & 6.2 & 1.8 & 2.9 & 9.4 \\
\hline Uganda & 21 & Paper and paper products & 58 & 32.8 & 23.3 & 3.4 & 110.3 \\
\hline Uganda & 22 & Printing and publishing & 110 & 2.7 & 0.6 & 1.7 & 4.3 \\
\hline Uganda & 24 & Chemicals and chemical products & 212 & 6.6 & 3.6 & 1.4 & 23.4 \\
\hline Uganda & 25 & Rubber and plastics products & 90 & 3.8 & 1.3 & 1.5 & 8.3 \\
\hline Uganda & 26 & Non-metallic mineral products & 71 & 461.0 & 474.0 & 6.2 & 2583.2 \\
\hline Uganda & 27 & Basic metals & 42 & 3.1 & 1.0 & 1.4 & 6.0 \\
\hline Uganda & 36 & Furniture; manufacturing n.e.c. & 106 & 18.5 & 12.0 & 4.7 & 84.3 \\
\hline
\end{tabular}

(Source) Author's calculations based on data from INDSTAT2 and COMTRADE online databases. 


\section{Appendix 6: Further robustness checks}

This appendix provides an assessment of the baseline results reported in Table 4, column (5), for endogeneity biases coming from mismeasurement of the total bilateral trade costs due to the use of mirror trade data for Kenya instead of data reported by Kenya, which has gaps. A comparison of the total bilateral trade costs estimates and the residuals from a general gravity model is also presented in this Appendix.

\section{A. Effect of using mirror trade data for Kenya}

Due to large gaps in the trade data reported by Kenya in COMTRADE, mirror data (or data reported by Kenya's trade partners) was used to estimate total bilateral trade costs between Kenya and its trade partners. A concern with using mirror data is that the missing export values that would have been reported by Kenya would be valued on a free on board (F.O.B.) basis (that is, not including freight and insurance charges) whereas data on values imported from Kenya as reported by partners are reported on a C.I.F. basis. The implication is that total bilateral trade costs estimates derived using data with C.I.F. valuation would be lower since the calculated value for domestic trade (the $x_{i i}^{k}$ term in Equation (3)) would be lower. ${ }^{9}$ To see whether total bilateral trade costs estimates based on mirror trade data are significantly lower than estimates based on data as reported by Kenya, the two sets of estimates are subjected to the $t$-test. The test results are reported in Table A1.

The results show that for EAC trade partners, the means of the two sets of trade costs estimates are not significantly different from each other. However, for non-EAC partners, there is a statistically significant difference in the means of the two sets of estimates for five industries. The use of mirror trade data is therefore a potential source of bias and it would be appropriate to conduct robustness checks on analyses using these estimates.

${ }^{9}$ Domestic trade is calculated as domestic production minus total exports to the rest of the world. 


\section{Table A1. Difference in means of total bilateral trade costs estimated from own and mirror trade data for Kenya}

\begin{tabular}{|c|c|c|c|c|c|c|c|c|}
\hline \multirow[b]{2}{*}{$\begin{array}{l}\text { ISIC code and } \\
\text { description }\end{array}$} & \multicolumn{4}{|c|}{ Kenya's trade with EAC partners } & \multicolumn{4}{|c|}{ Kenya's trade with non-EAC partners } \\
\hline & $\begin{array}{c}\text { Trade costs } \\
\text { calculated } \\
\text { from } \\
\text { mirror } \\
\text { trade data }\end{array}$ & $\begin{array}{c}\text { Trade costs } \\
\text { calculated } \\
\text { from trade } \\
\text { data } \\
\text { reported } \\
\text { by Kenya }\end{array}$ & $t$ stat. & $p$-value & $\begin{array}{c}\text { Trade costs } \\
\text { calculated } \\
\text { from } \\
\text { mirror } \\
\text { trade data }\end{array}$ & \begin{tabular}{|c|} 
Trade costs \\
calculated \\
from trade \\
data \\
reported \\
by Kenya \\
\end{tabular} & $t$ stat. & $p$-value \\
\hline 15 Food and beverages & 3.4 & 3.6 & -1.03 & 0.31 & 7.3 & 7.5 & -1.53 & 0.13 \\
\hline 16 Tobacco products & 1.7 & 2.0 & -1.24 & 0.25 & 2.5 & 2.5 & -0.38 & 0.71 \\
\hline 17 Textiles & 1.9 & 1.9 & -0.81 & 0.42 & 3.2 & 3.3 & -2.18 & 0.03 \\
\hline 18 Wearing apparel, fur & - & - & 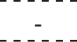 & 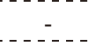 & 5.3 & 6.2 & -2.96 & 0.00 \\
\hline $19 \begin{array}{l}\text { Leather, leather } \\
\text { products and footwear }\end{array}$ & 4.9 & 4.2 & 0.91 & 0.37 & 8.7 & 9.7 & -2.03 & 0.04 \\
\hline $\begin{array}{l}\text { Wood products (excl. } \\
\text { furniture) }\end{array}$ & 4.5 & 5.3 & -0.57 & 0.57 & 17.4 & 17.5 & -0.16 & 0.88 \\
\hline $21 \begin{array}{l}\text { Paper and paper } \\
\text { products }\end{array}$ & 5.4 & 5.9 & -0.57 & 0.57 & 26.7 & 28.6 & -1.02 & 0.31 \\
\hline 22 Printing and publishing & 2.0 & 2.0 & 0.47 & 0.64 & 2.9 & 2.9 & -0.44 & 0.66 \\
\hline $23 \begin{array}{l}\text { Coke, refined } \\
\text { petroleum products, etc }\end{array}$ & - & - & - & - & 58.9 & 80.0 & -0.78 & 0.44 \\
\hline $24 \begin{array}{l}\text { Chemicals and } \\
\text { chemical products }\end{array}$ & 2.3 & 2.3 & 0.10 & 0.92 & 5.9 & 5.8 & 0.43 & 0.67 \\
\hline $25 \begin{array}{l}\text { Rubber and plastics } \\
\text { products }\end{array}$ & 1.9 & 1.9 & -0.17 & 0.87 & 3.9 & 3.9 & -0.43 & 0.67 \\
\hline $26 \begin{array}{l}\text { Non-metallic mineral } \\
\text { products }\end{array}$ & 24.9 & 23.6 & 0.28 & 0.78 & 502.5 & 524.0 & -0.43 & 0.67 \\
\hline 27 Basic metals & 1.6 & 1.6 & -0.01 & 0.99 & 3.1 & 3.0 & 1.23 & 0.22 \\
\hline $29 \begin{array}{l}\text { Machinery and } \\
\text { equipment n.e.c. }\end{array}$ & 1.4 & 1.4 & -0.99 & 0.34 & 1.8 & 1.9 & -3.27 & 0.00 \\
\hline $34 \begin{array}{l}\text { Motor vehicles, trailers, } \\
\text { semi-trailers }\end{array}$ & 3.3 & 3.4 & -0.16 & 0.88 & 8.3 & 9.7 & -2.80 & 0.01 \\
\hline $36 \begin{array}{l}\text { Furniture; } \\
\text { manufacturing n.e.c. }\end{array}$ & 5.1 & 5.2 & -0.21 & 0.84 & 16.2 & 17.4 & -1.97 & 0.05 \\
\hline
\end{tabular}

(Note) The null hypothesis under the $t$ test is that the difference between the means of the two data sets is zero.

Table A2 shows the baseline estimates of Equation (17), which are based on total bilateral trade costs estimates that incorporate mirror trade data for Kenya (column 1). The results reported in column (2) are obtained after restricting the sample for the baseline estimates to the years when Kenya reported data. Column (3) shows results based on total bilateral trade costs estimates that incorporate trade data reported by Kenya. The data that is reported by Kenya has gaps in years 1993 1996 and 2011 2012. I restrict the sample to the years when data reported by Kenya is available and remain with 7,388 observations. The baseline estimates (columns 1 and 2) are marginally greater than the estimates reported in column (3) but the difference is not significant. The baseline results are therefore not significantly biased by using mirror trade data for Kenya. 


\section{Table A2. Determinants of total bilateral trade costs, effect of using mirror trade data for Kenya}

\begin{tabular}{|c|c|c|c|}
\hline \multirow{3}{*}{ Dependent variable } & \multicolumn{3}{|c|}{ In(Total bilateral trade costs) } \\
\hline & \multicolumn{2}{|c|}{ Mirror trade data (baseline) } & \multirow{2}{*}{\begin{tabular}{|c|}
$\begin{array}{c}\text { Trade data reported } \\
\text { by Kenya }\end{array}$ \\
(3) \\
\end{tabular}} \\
\hline & (1) & (2) & \\
\hline $\ln$ (Bilateral distance) & $\begin{array}{c}0.356 * * * \\
(0.090)\end{array}$ & $\begin{array}{c}0.350 * * * \\
(0.108)\end{array}$ & $\begin{array}{c}0.347 * * * \\
(0.104)\end{array}$ \\
\hline Common border & $-0.302 * * *$ & $\begin{array}{c}-0.288 * * * \\
(0.091)\end{array}$ & $-0.286 * * *$ \\
\hline $\begin{array}{l}\text { Common language } \\
\text { (official) }\end{array}$ & $-0.200^{* *}$ & $\begin{array}{c}-0.187 * * \\
(0.086)\end{array}$ & $-0.194 * *$ \\
\hline Common colonizer & $\begin{array}{c}0.092 \\
(0.120)\end{array}$ & $\begin{array}{c}0.061 \\
(0.119)\end{array}$ & $\begin{array}{c}0.054 \\
(0.117)\end{array}$ \\
\hline Landlocked & $\begin{array}{l}-0.053 \\
(0.095)\end{array}$ & $\begin{array}{r}-0.081 \\
(0.105)\end{array}$ & $\begin{array}{r}-0.032 \\
-(0.097)\end{array}$ \\
\hline EAC membership & $-0.291^{* *}$ & $-0.265^{* *}$ & $\begin{array}{l}-0.260^{*} \\
(0.135)\end{array}$ \\
\hline COMESA membership & $\begin{array}{l}-0.061 \\
(0.050) \\
\end{array}$ & $\begin{array}{l}-0.034 \\
(0.057)\end{array}$ & $\begin{array}{l}-0.079 \\
(0.069)\end{array}$ \\
\hline $\begin{array}{l}\text { Exporter-year fixed } \\
\text { effects }\end{array}$ & Yes & Yes & Yes \\
\hline $\begin{array}{l}\text { Importer-year fixed } \\
\text { effects }\end{array}$ & Yes & Yes & Yes \\
\hline $\begin{array}{l}\text { Industry-year fixed } \\
\text { effects }\end{array}$ & Yes & Yes & Yes \\
\hline Observations & 11,095 & 7,388 & 7,388 \\
\hline Adjusted $R$-squared & 0.89 & 0.89 & 0.89 \\
\hline $\begin{array}{l}\text { Total bilateral trade } \\
\text { costs, mean }\end{array}$ & 8.0 & 7.8 & 8.0 \\
\hline
\end{tabular}

(Note) Table A2 shows OLS estimates of Equation (17). Results in columns (1) and (2) are estimated using mirror trade data for Kenya. Results in column (3) are estimated using trade data reported by Kenya, which has gaps in 1993 1996 and 2011 2012. In all cases, the data for all other countries is unchanged. The constant term is not shown in all cases. The standard errors in parentheses are clustered at the country-pair level. Significance levels: $* p<0.10, * * p<0.05, * * * p<0.01$.

\section{B. Correlation with residuals from a general gravity model}

Following Jacks et al. (2011), the total bilateral trade costs estimates are evaluated against the residuals from a general gravity model. According to the gravity equation, any changes in bilateral trade are due to changes in the GDPs of the trading countries and the world and/ or changes in the bilateral trade costs between the two countries and multilateral resistance (MLR). Once changes to the GDPs and MLR are controlled for, the residuals from a general gravity equation should give an indication of the bilateral trade costs of the country-pair. The residuals arising from a change in bilateral trade flows should correlate negatively with total 
bilateral trade costs since higher trade values (holding GDP and MLR constant) imply lower bilateral trade costs. The estimated general gravity equation is of the following form:

$$
\ln \left(x_{i j k, t} x_{j i k, t}\right)=\delta_{t}+\delta_{i, t}+\delta_{j, t}+\varepsilon_{i j k, t}
$$

where the logarithm of the product of the value of industry $k$ exports from exporter $i$ to importer $j$ at time $t$ and the value of industry $k$ exports from importer $j$ to exporter $i$ at time $t$, denoted by $\ln \left(x_{i j k, t} x_{j i k, t}\right)$, is regressed on year fixed effects, $\delta_{t}$, exporter-year fixed effects, $\delta_{i, t}$, and importer-year fixed effects $\delta_{j, t}$. The year fixed effects control for macroeconomic shocks that affect all countries. The exporter-year and importer-year fixed effects control for MLR as well as time-varying differences in the supply of and demand for goods across countries that influence their external trade. The error term $\varepsilon_{i j k, t}$ captures residual determinants of bilateral trade including bilateral trade costs.

Equation (A1) is estimated using OLS and data for each industry separately and using data that is pooled across the industries (that is, using all the industries' data at once). The residuals obtained from the regressions are then correlated with the natural logarithm of total bilateral trade costs estimates and the results presented in Table A3. The correlation coefficients between the model residuals and the total bilateral trade costs estimates are negative, indicating that the total bilateral trade costs estimates are reliable. 


\section{Table A3. Correlation coefficients between total bilateral trade costs and residuals from a general gravity equation}

\begin{tabular}{|l|c|c|}
\hline \multicolumn{1}{|c|}{ ISIC code and description } & $\begin{array}{c}\text { Based on OLS } \\
\text { estimates, by } \\
\text { industry }\end{array}$ & $\begin{array}{c}\text { Based on } \\
\text { pooled } \\
\text { OLS estimates }\end{array}$ \\
\cline { 2 - 3 } 15 Food and beverages & $\mathbf{( 1 )}$ & $\mathbf{( 2 )}$ \\
\hline 16 Tobacco products & -0.44 & -0.70 \\
\hline 17 Textiles & -0.16 & -0.73 \\
\hline 18 Wearing apparel, fur & -0.47 & -0.70 \\
\hline 19 Leather, leather products and footwear & -0.02 & -0.76 \\
\hline 20 Wood products (excl. furniture) & -0.35 & -0.68 \\
\hline 21 Paper and paper products & -0.45 & -0.55 \\
\hline 22 Printing and publishing & -0.35 & -0.64 \\
\hline 23 Coke, refined petroleum products, nuclear fuel & -0.38 & -0.62 \\
\hline 24 Chemicals and chemical products & -0.35 & -0.69 \\
\hline 25 Rubber and plastics products & -0.46 & -0.68 \\
\hline 26 Non-metallic mineral products & -0.43 & -0.68 \\
\hline 27 Basic metals & -0.43 & -0.71 \\
\hline 29 Machinery and equipment n.e.c. & -0.30 & -0.73 \\
\hline 34 Motor vehicles, trailers, semi-trailers & -0.23 & -0.56 \\
\hline 36 Furniture; manufacturing n.e.c. & -0.23 & -0.42 \\
\hline
\end{tabular}

(Note) Column (1) shows correlation coefficients between the natural logarithm of total bilateral trade costs and the residuals from estimation of Equation (A1) using data of each ISIC group separately. Column (2) shows correlation coefficients between the natural logarithm of total bilateral trade costs and the residuals from Estimation of equation (A1) using data that is pooled across ISIC groups.

Although this method of inferring trade costs from the residuals of a general gravity model is simpler, I prefer the inverse-gravity method because it uses observed production and trade data and considers the substitutability of goods. Besides, the baseline total bilateral trade costs estimates are less strongly correlated with the residuals from industryspecific regressions of Equation (A1) (see column (1), Table A3), perhaps indicating missing industry-specific information from the latter estimates. 